\title{
SECAGEM ESTACIONÁRIA DE SEMENTES DE MILHO COM DISTRIBUIÇÃO RADIAL DO FLUXO DE AR
}

\author{
CLÁUDIO CAVARIANI \\ Engenheiro Agrônomo
}

Orientador: Prof. Dr. Walter Rodrigues da Silva

Tese apresentada à Escola Superior de Agricultura "Luiz de Queiroz", da Universidade de São Paulo, para obtenção do Título de Doutor em Agronomia, Área de Concentração: Fitotecnia.

PIRACICABA

Estado de São Paulo-Brasil

Outubro-1996 
Dados Internacionais de Catalogação na Publicaçăo (CIP) DIVISÃO DE BIBLIOTECA E DOCUMENTAÇĀO - Campus "Luiz de Queiroz"/USP

\section{Cavariani, Cláudio}

Secagem estacionária de sementes de milho com distribuição radial do fluxo de ar / Cláudio Cavariani. - - Piracicaba, 1996.

85p. : il.

Tese (doutorado) - Escola Superior de Agricultura Luiz de Queiroz, 1996.

Bibliografia

Milho - Semente - Qualidade 2. Semente - Secagem - Efeito I. Titulo

CDD 633.15

631.521 


\section{SECAGEM ESTACIONÁRIA DE SEMENTES DE MILHO COM DISTRIBUIÇÃO RADIAL DO FLUXO DE AR}

CLÁUDIO CAVARIANI

Aprovada em: 05/12/1996

Comissão Julgadora:

Prof. Dr. Walter Rodrigues da Silva

ESALQ/USP

Prof. Dr. Sílvio Moure Cícero

ESALQ/USP

Prof. Dr. Luiz Fernandes Razera

Prof. Dr. João Nakagawa

IAC

Prof. Dr. Rubens Sader.

FCA/UNESP

FCAVJIUNESP

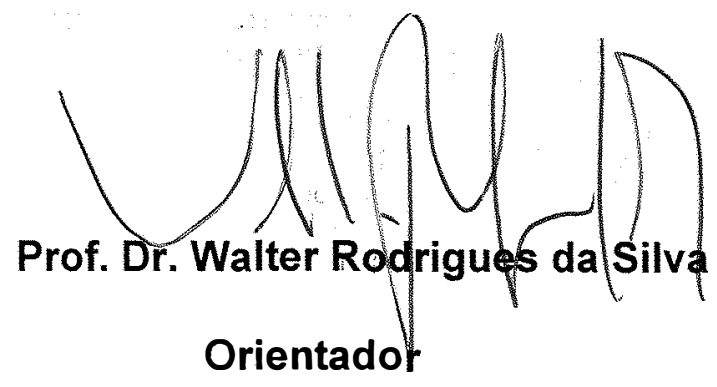


A meus pais José (in memorian) e Lídia, a meus irmãos Hamilton (in memorian), Eclair e Egberto

A minha esposa, Maria Célia, e minhas filhas, Claudia e Mariana

A meus amigos 


\section{AGRADECIMENTOS}

Ao Prof. Dr. Walter Rodrigues da Silva, pela orientação, consideração, amizade e palavras oportunas.

Ao corpo docente da ESALQ/USP, especialmente aos Professores Doutores Francisco Ferraz de Toledo, Silvio Moure Cicero, José Otávio Machado Menten, Murilo de Melo, Gil Miguel de Souza Câmara, Geraldo J. A. Dario, José Carlos Chitolina, Maria Emília Mattiazzo Prezotto e Décio Barbin pela atenção e apoio.

Aos colegas do Departamento de Agricultura e Melhoramento Vegetal, FCA/UNESP, em especial aos Professores Doutores João Nakagawa, Edivaldo Domingues Velini, Silvio José Bicudo, Norberto da Silva e Maurício Dutra Zanotto pelo incentivo e apoio.

Ao Engenheiro Agrônomo Andrés Enrique Lai Reyes, pela valiosa colaboração nas análises estatísticas.

Aos colegas de curso, particularmente a Luiz Carlos Miranda, Édila Vilela de Resende Von Pinho, Denise Augusta C. Billia, Maria Cristina M. Spindola e Monaliza Alves Diniz, pela colaboração e momentos compartilhados. Às Engenheiras Agrônomas Helena Maria C. P. Chamma e Ana

Dionisia C. L. Novembre, e aos Senhores João Elias Jabur Filho, Carlos Adversi Carlet e João Batista Bigelli, pela efetivo auxílio. 
Às Senhoras Ilze Helena C. G. das Neves e Maria Aparecida T. Soledade, e aos Senhores Adilson de Jesus Teixeira, Ananias Ferreira de Souza, Antonio Arruda, Antonio Pereira de Andrade, Celestino Alves Ferreira, Claudinei Martins Valério, Cláudio do E. S. Ferraz, Daniel Luiz Theodoro, Hodair Luiz Banzatto Junior, Jair Vitório Arthur, João Romildo Barbieri, João Rodrigues, José dos Reis L. Santos, José Soares de Almeida, Osvaldo de Jesus Pelissari e Wilson Goes da Silva pela colaboração e companheirismo.

Aos acadêmicos Daniella Côrtes Belgiorno, Fabiana Cristina B. Romano, Sacha Silva Savietto, Rodrigo Meirelles S. Pimentel e Ricardo Augusto de Souza pela amizade e valioso auxílio quando das determinações laboratoriais.

Aos acadêmicos do Grupo de Experimentação Agrícola pela colaboração efetiva.

À Biologa Raquel Foroni Castelani e à Engenheira Agrônoma Maria Heloisa D. Moraes pela valiosa ajuda na execução dos testes de sanidade.

Às Senhoras Kátia Maria de Andrade Ferraz, Eliana Maria Garcia Sabino e Roseli Cappelletti pelo sorriso oportuno.

À empresa Sementes Agroceres S/A, Unidade de Santa Cruz das Palmeiras, S.P., nas pessoas dos Engenheiros Agrônomos Vilson Antonio da Rocha, Carlos Alberto Ribeiro Gonçalves, Edson Marcos Gonçalves e Luis 
Cláudio Silva, e dos Senhores funcionários, especialmente, Walter Vitório Cecarello, Mauro Celso Ortolani, Marcos Antonio Fiorini, Carlos Fonseca da Silva Neto, Sebastião Pereira, João Inácio Rodrigues, Wagner Luís Cassiano, Ayres Aguinaldo Venzi, Fernando Varisi, Wagner Luís da Silva, Luíz Paulo Rodrigues, Everaldo Carlos Coleti, José Luís Marera e André Luís Gonçalves, pelas sugestões, apoio e suporte para execução deste trabalho.

À ROTA Indústria de Máquinas Agrícolas Ltda., pelo apoio e cessão de equipamentos.

À CWA, na pessoa do Engenheiro Mecânico Seiki Kamisato, pelas sugestões e colaboração efetiva na condução deste trabalho.

À FCA/UNESP, CAPES/PICD e FAPESP pela oportunidade de realização do doutoramento e pelo suporte financeiro.

A todos que, direta ou indiretamente, contribuiram para a realização do curso. 


\section{INDICE}

Página

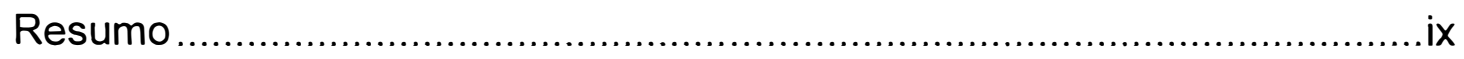

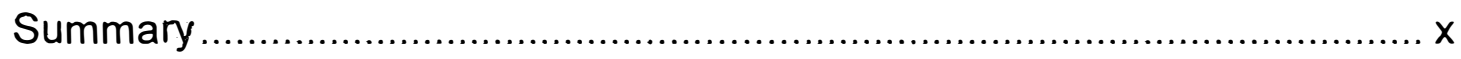

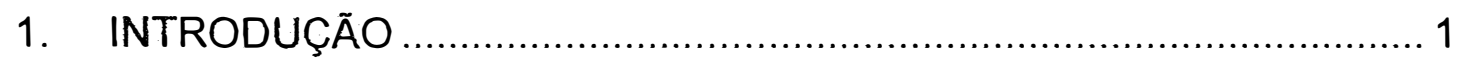

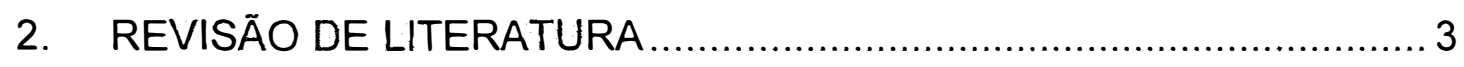

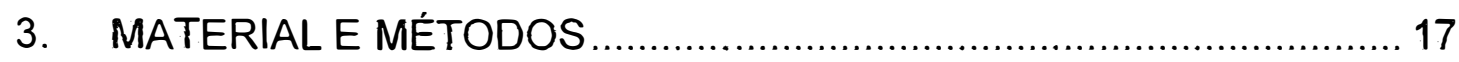

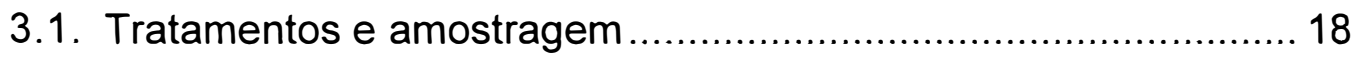

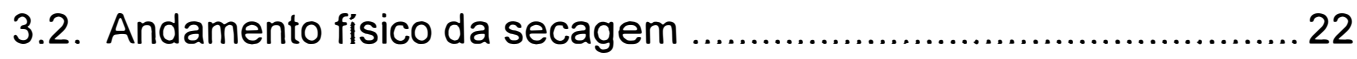

3.2. 1. Temperatura e umidade relativa do ar ambiente............ 22

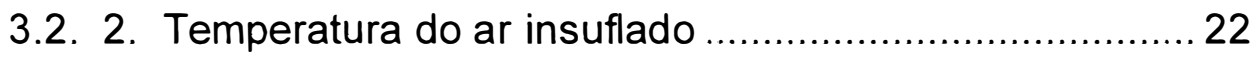

3.2. 3. Umidade relativa e pressão de vapor do ar insuflado ....22

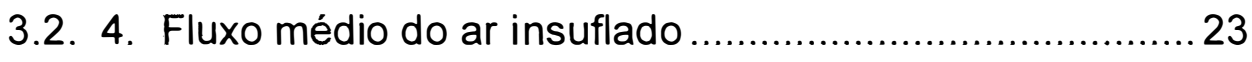

3.2. 5. Pressão estática do ar insuflado ................................ 23

3.2. 6. Temperatura da massa de sementes.......................... 23

3.2. 7. Variação da temperatura na massa de sementes.......... 24

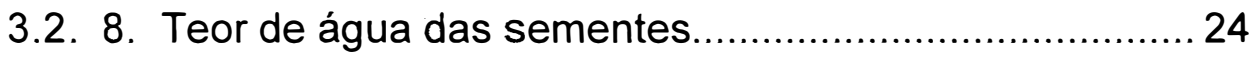

3.2. 9. Variação do teor de água na massa de sementes.........24 
3.2.10. Teor de água médio ponderado da massa de sementes 24

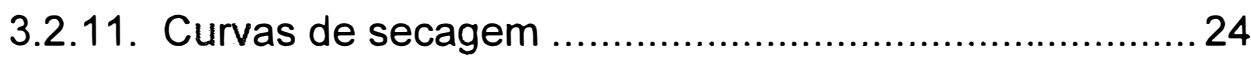

3.2.12. Velocidade média de secagem .................................... 25

3.2.13. Velocidade média ponderada de secagem da massa de

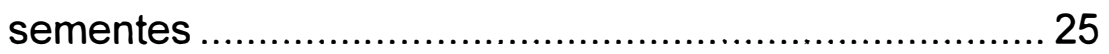

3.3. Conseqüências provocadas às sementes .............................. 25

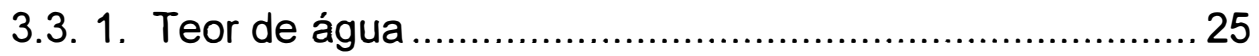

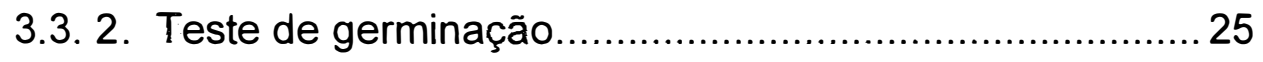

3.3. 3. Teste de envelhecimento artificial ................................26

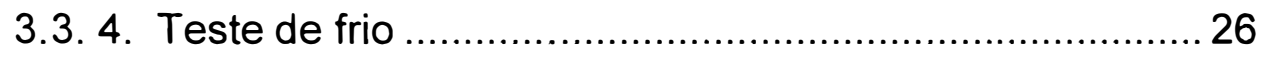

3.3. 5. Teste de emergência das plântulas em campo............... 26

3.3. 6. Teste de condutividade elétrica..................................... 27

3.3.7. Teste de comprimento de raiz ..................................... 27

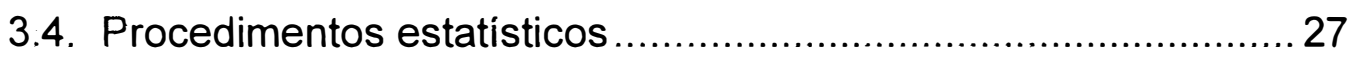

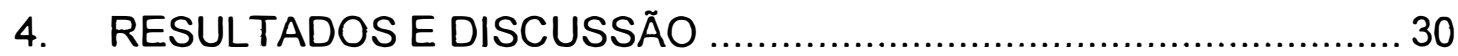

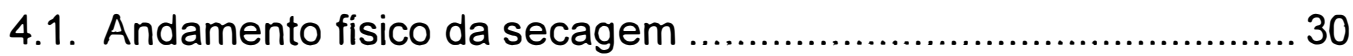

4.2. Conseqüências provocadas às sementes …............................ 59

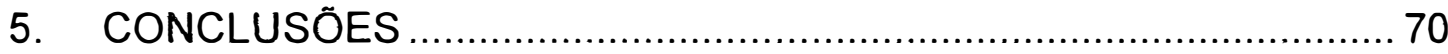

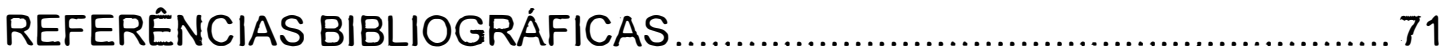




\title{
SECAGEM ESTACIONÁRIA DE SEMENTES DE MILHO COM DISTRIBUIÇÃO RADIAL DO FLUXO DE AR
}

\author{
Autor: Cláudio Cavariani \\ Orientador: Prof. Dr. Walter Rodrigues da Silva
}

\section{RESUMO}

A pesquisa, conduzida com sementes de milho, cv AG-303, estudou as conseqüências das variações no fluxo e na temperatura do ar insuflado, considerando o tempo do processo e a posição das sementes na massa. Para tanto, foram caracterizados 0 ar ambiente, 0 ar insuflado, as temperaturas e os teores de água da massa, as velocidades de secagem, as equações de secagem e a qualidade fisiológica das sementes no armazenamento.

Foi concluído que, admitindo os intervalos de 18,6 a 24,7 $\mathrm{m}^{3} / \mathrm{min} . / \mathrm{t}$ e de 40 a $48^{\circ} \mathrm{C}$, respectivamente para o fluxo e a temperatura do ar insuflado, o aumento conjunto nos valores de ambos os fatores, além de físicamente eficiente, permite evitar efeitos negativos, advindos da secagem, na qualidade fisiológica de sementes de milho. Dessa forma, a combinação de $24,7 \mathrm{~m}^{3} / \mathrm{min} . / \mathrm{t} \mathrm{com} 48^{\circ} \mathrm{C}$ pode ser recomendada. 


\section{STATIONARY DRYING OF CORN SEEDS WITH RADIAL FLOWING AIR DISTRIBUTION}

Author: Cláudio Cavariani

Adviser: Prof. Dr. Walter Rodrigues da Silva

SUMMARY

The present research had studied the consequences of variations of flowing air temperatures and drying period on different positions of corn seed mass, cv AG 303, submitted to the drying process.

Utilizing environmental and injected air temperature, seed moisture and different drying air speed, drying equations were stablished and physiological seed quality was studied during storage period.

It is concluded that the increase of flowing air betwen 18,6 and $24,7 \mathrm{~m}^{3} / \mathrm{min} . / \mathrm{t}$ and temperature betwen 40 and $48^{\circ} \mathrm{C}$ increase seed drying efficiency and prevent negative effects on physiological corn seed quality. In that way combination of $24,7 \mathrm{~m}^{3} / \mathrm{min}$. $/$ t with $48^{\circ} \mathrm{C}$ can be recomended. 


\section{INTRODUÇÃO}

Considerando que as sementes, por ocasião da colheita, nem sempre se apresentam com teores de água compativeis com os exigidos para o seu armazenamento, pode-se admitir a secagem como item necessariamente demandador de atenção nas atividades relacionadas com a produção.

A secagem pode ser entendida, em linhas gerais, como sendo o processo promotor do deslocamento de uma determinada quantidade de água, segundo as diferenças de potencial hídrico existentes, de um dado sistema para outro. Assim, ao se tratar tecnologicamente da secagem das sementes, subentende-se esta massa biológica como sistema doador de água e a atmosfera como receptor.

O uso do calor, pelas facilidades operacionais e econômicas que apresenta, tem sido o meio historicamente mais empregado para promover a secagem das sementes. Contudo, em virtude da variabilidade existente entre métodos, equipamentos e ambiente, persistem dúvidas tecnológicas quanto às 
condutas a serem adotadas para as obtenções dos melhores resultados de eficiência e de qualidade no produto final.

Dessa maneira, a presente pesquisa objetiva buscar conhecimentos relacionados ao emprego de secador estacionário, com cilindro central perfurado e distribuição radial de ar, na retirada de água das sementes. Para tanto, sob diferentes temperaturas e fluxos do ar de secagem, foram estudados 0 andamento físico da secagem e as conseqüências provocadas nas sementes de milho. 


\section{REVISÃO DE LITERATURA}

Muito embora a secagem constitua o método mais antigo para a conservação de matérias primas agropecuárias, é desconhecido o momento, ao longo da história, em que o homem percebeu a sua importância (Roa \& Villa, 1977; Carvalho, 1994).

A secagem natural das sementes prevalece em paises com condições climáticas favoráveis para tal, em razão de requerer instalações simples e baratas. Mesmo apresentando desvantagens, para determinadas espécies vegetais, como as de algumas gramíneas forrageiras, é um processo recomendado por diversos pesquisadores (Macêdo et al., 1987; Magalhães \& Groth, 1992).

Com referência à secagem artificial, existem registros da sua utilização no século XIX nos Estados Unidos (Foster, 1973). Entretanto foi particularmente após a $2^{\mathrm{a}}$ Grande Guerra, face às necessidades de industrialização, que a secagem artificial evoluiu com a geração de novas tecnologias. 
No Brasil, verificou-se a adoção das tecnologias de secagem geradas no exterior. Entretanto, Rosa $(1966,1968)$ destacou a necessidade do desenvolvimento de trabalhos sobre secagem, visando o aprimoramento da tecnologia de produção de sementes, especialmente na região sul. Quando a pesquisa em sementes se intensificou e a indústria de equipamentos foi incentivada, trabalhos relacionados com secagem, embora inicialmente em número reduzido, mereceram atenção de vários pesquisadores (Andrigueto \& et al., 1976; Gonzales et al., 1979; Miranda, 1978; Alvarenga, 1979; Cerqueira, 1979).

$\mathrm{Na}$ década de 80 as pesquisas envolveram diversos tipos de equipamentos, contemplando, principalmente, a temperatura do ar e o sistema de secagem (Corrêa, 1981; Cavariani, 1983; Bounos, 1986; Luz, 1986; Vega, 1989). Ultimamente, outros parâmetros, como umidade relativa e fluxo de ar de secagem, passaram a receber atenção em experimentos, todavia em escala não comercial (Rangel, 1994; Claser, 1995).

A semente e a atmosfera que a rodeia são sistemas que se acham em permanente troca de água, com sentido preferencial definido pela diferença de potencial hídrico existente entre ambos. A predominância de fluxo hidrico se dará do sistema que se encontra com maior potencial para o que se encontra com menor grandeza nesta propriedade, até que seja atingido o ponto de equilibrio higroscópico (Silva, 1986). O processo de secagem, em sementes, 
é o resultado da existência de potencial hídrico inferior, na atmosfera, ao presente nas sementes; com isso, a passagem de água ocorre, predominantemente, no sentido semente-atmosfera até que seja atingido um ponto de equilíbrio higroscópico representado por teor de água inferior ao existente originalmente nas sementes.

A secagem também é entendida como o processo simultâneo de transferência de calor, do ar para as sementes, e de massa (água), das sementes para o ar (Brooker et al., 1974). Em consequência da demanda de energia calorífica para a evaporação da água, ocorre resfriamento do ar de secagem pela perda de calor sensível. Entretanto, o balanço energético é nulo em razão do ar recuperar, na forma de vapor de água (calor latente), o que perdeu na forma de calor sensivel (Brooker et al., 1974; Lasseran, 1978). Por essa razão, a secagem é considerada processo adiabático ou isoentálpico. Durante sua execução verifica-se redução da temperatura do ar e aumentos da razão de mistura, da umidade relativa, da pressão de vapor e da temperatura do ponto de orvalho; a entalpia e a temperatura do bulbo úmido permanecem, praticamente, constantes.

Os métodos de secagem classificam-se, quanto ao uso de equipamentos (natural ou artificial), quanto à periodicidade no fornecimento de calor (contínuo ou intermitente) e quanto à movimentação da massa trabalhada 
(estacionário ou contínuo) (Kreyger, 1973; Brooker et al., 1974; Lasseran, 1979; Peske \& Baudet, 1980; Peske \& Aguirre, 1987; Carvalho, 1994).

A secagem natural, em larga escala, apresenta desvantagens decorrentes do intenso uso de mão de obra, uma vez que as operações, fundamentalmente manuais, geram baixo rendimento; paralelamente, o processo é totalmente dependente das condições climáticas disponiveis (Roa \& Villa, 1977; Carvalho \& Nakagawa, 1988; Carvalho, 1994).

Na secagem artificial, a fonte calórica pode ser variável. $\mathrm{O}$ que caracteriza um método como artificial é o fato de que o processo é executado com o auxílio de alternativas mecânicas, elétricas ou eletrônicas e o ar, que atravessa a massa de sementes, é forçado. Tendo em vista a rapidez com que consegue remover água, tem sido a opção mais freqüentemente adotada na produção de sementes.

A secagem estacionária consiste, basicamente, em forçar a passagem do ar através da massa de sementes que permanece em repouso. Existem vários modelos de secadores estacionários. Nos de fundo falso perfurado, a secagem se processa da base para o topo da camada de sementes e, nos de tubo central perfurado, do centro para a periferia; ocorre em camadas, em função da formação da frente de secagem, correspondentes às regiões de intercâmbio de água entre as sementes e o ar. $\mathrm{Na}$ região anterior, à da frente de secagem, permanecem as sementes secas e alta 
temperatura e, na posterior sementes úmidas e baixa temperatura (Welch, 1967; Peske \& Baudet, 1980; Cavariani \& Baudet, 1982).

A pressão estática, ou perda de pressão, refere-se à resistência imposta ao caminhamento do ar forçado a atravessar a massa de sementes, como conseqüência de perdas de energia por fricção e turbulência; depende da arquitetura dos ductos, do fluxo do ar, das características físicas da cobertura protetora das sementes, do volume e arquitetura dos espaços porosos, da uniformidade dos componentes e da espessura da massa (Brandenburg et al., 1961; Brooker et al., 1974). O efeito do teor de água das sementes, na pressão estática, não é claro segundo Brooker et al. (1974). Shedd (1953) constatou, sob fluxo constante de ar, redução na pressão estática em milho à medida em que o teor de água aumentava, inversamente ao observado por Patterson, citado por Brooker et al.(1974).

Fazendo referência aos silos secadores com distribuição radial de ar, Mclean (1980) ponderou que a reduzida espessura da massa, e as características aerodinâmicas favoráveis, fazem com que a pressão estática seja baixa, o que possibilita a utilização de fluxos de ar próximos a $30 \mathrm{~m} / \mathrm{min} / \mathrm{t}$.

O fluxo de ar deve ser suficiente para não tornar-se saturado antes que deixe a massa de sementes (Boyd et al., s.d.; Brandenburg et al., 1961), podendo ser aumentado até que seja capaz de absorver toda a água liberada pelas sementes. A partir desse ponto, a movimentação da água, do 
interior para a superfície das sementes, torna-se o principal fator a influenciar o tempo de secagem. Desse modo, conforme Boyd (1974), nos silos secadores com distribuição axial do ar, há a necessidade de ajuste entre o fluxo do ar e a espessura da massa para minimizar o tempo de secagem e os efeitos negativos na qualidade das sementes. Em trabalho sobre secagem de sementes de soja com $22 \%$ de água, altura da massa de $1,20 \mathrm{~m}$ e umidade relativa do ar entre 42 e $55 \%$, Boyd et al. (s.d.) concluíram serem exigidos fluxos de 6,6 à $13,2 \mathrm{~m} / \mathrm{min} / \mathrm{t}$ e umidade relativa entre 40 e $50 \%$ no ar insuflado.

O modo, como se processa a secagem estacionária, origina gradientes de temperatura e de umidade (Welch, 1967; Brooker et al., 1974; Mclean, 1980; Corrêa, 1981; Cavariani \& Baudet, 1982; Pasin, 1991). Em secador estacionário com distribuição radial de ar, sob temperatura de $42^{\circ} \mathrm{C}$, Corrêa (1981) não observou diferenças entre as temperaturas das sementes de arroz mais próximas ao tubo central e as das mais afastadas. Contrariamente, Pasin (1991), em soja, constatou gradientes de até $15^{\circ} \mathrm{C}$ em secadores similares.

O gradiente do teor de água, entre sementes diferentemente distanciadas em relação ao ponto de entrada do ar, depende da umidade relativa, da temperatura e fluxo do ar, do teor de água e espessura da massa e da capacidade de transferência de água das sementes para o ar; é diminuído com reduções de temperatura e espessura da massa e com a elevação no 
fluxo de ar. Nas camadas mais distantes da entrada do ar, pode ocorrer aumento do teor de água das sementes em conseqüência da condensação provocada pela passagem do ar úmido por camada com temperaturas mais baixas (Brooker et al., 1974).

Resultados de Corrêa (1981) revelaram, em média, gradientes de $3,3 \%$ de água entre camadas de sementes de arroz, próximas e distantes da entrada de ar aquecido, em secador estacionário de fluxo radial; em soja, Pasin (1991) encontrou valores de 3,7 a 5,6\% entre camadas, em secadores de mesmo tipo, ao final de 8 horas de secagem. Segundo Mclean (1980) e Pasin (1991), esse gradiente não causa problemas qualitativos ao lote pois, quando da descarga, ocorre mistura de sementes suficiente para equalizar a distribuição de umidade pela massa.

A susceptibilidade das sementes ao dano físico é determinada pelo teor de água e temperatura da semente, genótipo, temperatura do ar, método e velocidade de secagem, velocidade de resfriamento, tamanho e forma das sementes (Gustafson et al., 1978; Gustafson \& Morey, 1979; Gunasekaran \& Paulsen, 1985).

O processo de secagem pode gerar trincas e fissuras, que tornam as sementes susceptíveis à quebra total em operações subsequentes (Gustafson et al., 1978; Gustafson \& Morey, 1979). Em sementes, as principais conseqüências de trincas e fissuras são a redução da capacidade de regular 
trocas hídricas e gasosas e o aumento da susceptibilidade à ação negativa de microrganismos, insetos e produtos quimicos de tratamento (Moore, 1974; Soave \& Moraes, 1987; Wetzel, 1987; Carvalho \& Nakagawa, 1988). Esses tipos de danos são, segundo Brooker et al. (1974), particularmente importantes nas secagens de sementes de arroz, milho e soja, podendo ser evitados pela utilização de baixas temperaturas e da associação entre altas temperaturas e altas umidades relativas do ar, como formas de proporcionar equilibrio entre as secagens periférica e central de cada semente.

Brooker et al. (1974) enfatizaram que temperaturas de secagem devem ter, como referência, a da massa de sementes; assim, valores situados entre 40,5 e $43,3^{\circ} \mathrm{C}$ são considerados como máximos e, acima dos quais, danos físicos ou químicos podem ser gerados. No entanto, em função da diferença entre as temperaturas do ar insuflado e as da massa de sementes depender do tipo de secador, espécie considerada e resistência ao movimento do ar, torna-se necessário estabelecer o padrão da temperatura para cada tipo de secador e para cada espécie.

A causa primária do dano produzido por altas temperaturas em tecidos vegetais é, conforme Daniel et al. (1969), a desintegração das membranas celulares, possivelmente, por alterações nos lipídios que as constituem. Paralelamente, é aceita a teoria de que o calor excessivo provoca, entre outras alterações, a desnaturação de proteinas. Segundo Herter \& Burris 
(1989a), danos térmicos às sementes são caracterizados quando promovem a ruptura em ligações peptídicas de proteínas e em outros componentes celulares, tendo sido constatado que o início do efeito deletério, durante secagem à alta temperatura, coincidiu com o início da secagem do embrião; contudo, não foi possivel concluir se a perda de água do embrião é a causa fundamental da injúria, embora possa determiná-la.

Os danos fisiológicos, provocados pela secagem, podem se refletir em alterações nos sistemas subcelulares incluindo cromossomas (Roberts, 1972; 1981) e mitocôndrias (Madden, 1992), na redução do número de grãos de amido no eixo embrionário, nos aumentos de lixiviação de eletrólitos e açúcares e de produção de pigmentos carotenóides (Seyedin et al., 1984), em reduções da permeabilidade de membranas celulares (Seyedin et al., 1984; Herter \& Burris, 1989c) e da taxa respiratória (Madden, 1992).

De acordo com Herter \& Burris (1989a) e Chen \& Burris (1990), o estádio de maturação das sementes e a temperatura de secagem são fatores importantes para que seja conseguida secagem adequada. Com a progressiva perda de água, as sementes de milho tornam-se mais tolerantes à elevação de temperatura, ficando em torno de $40 \%$, conforme Herter \& Burris (1989d), o teor de água correspondente à transição de intolerância para tolerância a moderadas temperaturas. A tolerância de sementes de milho às altas 
temperaturas de secagem varia, adicionalmente, entre linhagens, estando associada à herança maternal (Navratil \& Burris, 1984; Bdliya \& Burris, 1988).

Trabalho de Herter \& Burris (1989d) mostrou que a présecagem, de sementes de milho em espiga a $35^{\circ} \mathrm{C}$, resultou em tolerância à secagem posterior sob temperatura de $50^{\circ} \mathrm{C}$; o tempo de exposição e a redução do grau de umidade, durante a pré-secagem, foram admitidos como os fatores de indução à tolerância.

Koster \& Leopold (1988) realizaram secagem de sementes de milho, soja e ervilha, até teor de água de $8 \%$, que é considerado prejudicial aos tecidos intolerantes à dessecação. A perda da tolerância à secagem correspondeu ao momento de lixiviação de oligossacarídeos que apresentam, como uma das suas funções, prevenir a cristalização da sacarose; a sacarose, na sua forma não cristalina, estabiliza as membranas repondo água para manutenção da sua estrutura. Paralelamente, houve aumento no teor de monossacarídeos redutores nos eixos embrionários que, potencialmente, podem causar danos às proteínas e ácidos nucleicos, afetando a viabilidade das sementes. Chen \& Burris (1990) concluiram que, além da sacarose, a rafinose atua na estabilização das membranas, contribuindo para a tolerância à secagem. Essas constatações concordam com as de Koster \& Leopold (1988), que verificaram, após o armazenamento, que as sementes de milho com $96 \%$ de germinação continham sacarose e rafinose, com $12 \%$ continham apenas 
sacarose e, as que não germinaram, continham glucose e frutose em lugar de sacarose e rafinose.

O aumento quantitativo de fosfolipídios, durante présecagem sob baixa temperatura, levou Chen \& Burris (1991) a relevar a importância desses compostos, particularmente fosfatidilcolina, na tolerância à secagem posterior sob alta temperatura, por agirem na estabilização estrutural das membranas celulares.

A sensibilidade fisiológica ao dano térmico é, segundo diferentes autores, função da espécie, genótipo, teor de água, temperatura, tempo de exposição e velocidade de secagem (Meier, 1983; Navratil \& Burris, 1984; Herter \& Burris, 1989b).

Purdy \& Crane (1967b) e Navratil \& Burris (1984) observaram diferenças, dependentes do genótipo, no comportamento de sementes de milho submetidas à secagem; os resultados indicaram, fixadas as condições operacionais, que os genótipos com maior velocidade de secagem apresentaram, paralelamente, maior resistência aos danos que, por sua vez, tiveram intensidade dependente do teor de água existente nas sementes postas para secar.

Segundo Harrington (1972), sementes mais úmidas são mais susceptiveis aos danos térmicos, razão pela qual sugeriu que, quanto maior o teor de água, menor deve ser a temperatura empregada. Porém, Brandenburg 
et al. (1961) ponderaram que a água superficial pode ser retirada sob alta temperatura do ar, uma vez que o processo de evaporação remove calor suficientemente para não alterar a temperatura das sementes; abaixo de $30 \%$ de água, no entanto, a quantidade de água, para evaporação, é menos rapidamente disponível e a temperatura da massa tende a aumentar.

Para Herter \& Burris (1989b), altas velocidades de secagem, representadas por taxas de $2 \%$ por hora, obtidas através de expressivo fornecimento de calor à massa de sementes, seriam as principais geradoras de injúrias.

A taxa de secagem resulta da velocidade de evaporação da água da semente, relacionada à velocidade de movimentação da água do seu interior para a superfície, e depende, fundamentalmente, da umidade, da temperatura e do fluxo de ar empregado (Matthes \& Rushing, 1972); paralelamente, é influenciada pela espessura e permeabilidade do pericarpo (Purdy \& Crane, 1967a), pelo genótipo, pelo estádio de maturação e pelo teor de água (Cross, 1985).

A remoção de $0,3 \%$ de água por hora, sob fluxo de $5,5 \mathrm{~m}^{3} / \mathrm{min} / \mathrm{t}$ a $43,3^{\circ} \mathrm{C}$, foi sugerida por Brandenburg et al. (1961) como regra genérica a ser utilizada em secagem de sementes.

A velocidade de secagem apresenta relação inversamente proporcional com a umidade relativa do ar (Westerman et al., 1973). No 
entanto, podem ser provocadas trincas e fissuras na cobertura protetora das sementes de milho, em umidades relativas do ar inferiores à 60\% (Westerman et al., 1973), e de soja, com valores inferiores à 40\% (Boyd, s.d.; Boyd, 1974; Boyd et al., s.d.). Também Herter \& Burris (1989b) constataram deterioração mais rápida em sementes de milho secadas sob $50{ }^{\circ} \mathrm{C}$ e $20 \%$ de umidade relativa do ar que sob $50^{\circ} \mathrm{C}$ e $60 \%$.

O inconveniente da utilização de ar com baixa umidade relativa, na secagem estacionária, é a possibilidade de redução excessiva no teor de água das sementes mais próximas à entrada do ar aquecido. Em silo secador de fluxo radial de ar, Pasin (1991) detectou secagem excessiva em $10 \%$ do volume total de sementes de soja que, aparentemente, não foram negativamente afetadas pela ocorrência. Referindo-se ao milho em espigas, Herter \& Burris (1989a) destacaram a ausência de qualquer efeito negativo da secagem excessiva, sob temperatura de $40{ }^{\circ} \mathrm{C}$, na qualidade das sementes. Contudo, Roberts (1981) sugeriu que, antes de afetar a porcentagem de germinação ou o desenvolvimento das plântulas normais, a secagem excessiva reduz a velocidade de germinação e, em casos mais severos, eleva a freqüência de anormalidades nas plântulas.

Desse modo, a realização da secagem de sementes exige a compatibilização entre os procedimentos operacionais relativos ao rendimento físico do processo e os voltados à preservação fisiológica das sementes. Para 
tanto, há a necessidade de continuidade na busca de informações capazes de ampliar a base de conhecimentos sobre o tema. 


\section{MATERIAL E MÉTODOS}

O presente trabalho, conduzido experimentalmente no periodo de fevereiro à dezembro de 1995, foi realizado na Unidade de Beneficiamento e Laboratório de Análise de Sementes da empresa Sementes Agroceres S.A., em Santa Cruz das Palmeiras/SP, e no Laboratório de Análise de Sementes do Departamento de Agricultura da Escola Superior de Agricultura "Luiz de Queiroz"/USP, em Piracicaba/SP.

Foram utilizadas $90 \mathrm{t}$ de sementes de milho híbrido duplo AG303 produzidas, na safra 1994/1995, pela Sementes Agroceres S.A., Unidade de Santa Cruz das Palmeiras, SP.

Imediatamente após a colheita, transporte à granel e recepção na unidade de beneficiamento, as sementes passaram por máquina de prélimpeza, para aproveitamento, exclusivo, da fração retida entre as peneiras sequenciais com crivos oblongos de $9,8 \times 19 \mathrm{~mm}(25 / 64$ " $\times 3 / 4$ ") e redondos de $4,7 \mathrm{~mm}(12 / 64 ")$. 
Seguiu-se a aplicação da secagem em secador estacionário com cilindro central perfurado e distribuição radial de ar. A fornalha metálica, da marca CWA, mod W 01, capaz de fornecer $144.000 \mathrm{kcal} / \mathrm{h}$, foi acoplada a ventilador centrífugo (10 cv) dotado de polias intercambiáveis para possibilitar alterações de rotação e, consequentemente, de fluxo de ar.

\subsection{Tratamentos e amostragem}

Foram utilizados três fluxos e três temperaturas do ar insuflado. Cada combinação entre fluxo e temperatura do ar constituiu uma secagem isolada com duração ininterrupta de 9 horas (Tabela 1).

Tabela 1. Fluxos $\left(\mathrm{m}^{3} / \mathrm{min} . / \mathrm{t}\right)$ e temperaturas $\left({ }^{\circ} \mathrm{C}\right)$ dos tratamentos de secagem.

\begin{tabular}{cc}
\hline \hline FLUXOS $(\mathrm{F})$ & $\begin{array}{c}\text { TEMPERATURAS }(\mathrm{T}) \\
\mathrm{m}^{3} / \mathrm{min} . / \mathrm{t}\end{array}$ \\
\hline \hline 18,6 & 40 \\
20,3 & 40 \\
24,7 & 40 \\
\hline 18,6 & 44 \\
20,3 & 44 \\
24,7 & 44 \\
\hline 18,6 & 48 \\
20,3 & 48 \\
24,7 & 48 \\
\hline \hline
\end{tabular}

A amostragem das sementes realizada durante a secagem, com o emprego de amostrador duplo septado especialmente desenvolvido para o experimento (Figura 1), considerou três distâncias $\left(D_{1}=17 \mathrm{~cm} ; D_{2}=34\right.$ 
$\mathrm{cm} ; D_{3}=51 \mathrm{~cm}$ ) radiais em relação ao cilindro central de insuflação de ar; cada distância foi representada pela reunião de subamostras coletadas em três alturas $\left(H_{1}, H_{2}, H_{3}\right)$ equidistantes de 2,0 m entre si. $A$ altura $H_{1}$ situou-se a 0,9 $m$ da base do secador (Figura 2.1). As repetições estatísticas foram definidas através da subdivisão axial do secador em três partes (Figura 2.2).

As amostragens foram realizadas, ao longo do tempo de secagem, em intervalos de $1,5 \mathrm{~h}$, para o estudo do andamento físico da secagem e, de $3,0 \mathrm{~h}$, para o estudo das consequências provocadas às sementes. Para este último, os materiais amostrados foram submetidos, quando necessário, à secagem complementar à baixa temperatura $\left(31\right.$ a $\left.34^{\circ} \mathrm{C}\right)$, até que as sementes atingissem cerca de $11-12 \%$ de água, com acompanhamento periódico da redução do grau de umidade. A seguir, foram realizados, manualmente, a remoção das sementes quebradas ou apodrecidas e o peneiramento para uniformização da largura e espessura das sementes. A fração útil correspondeu à retida entre as peneiras com crivos oblongos de 6,3 x $19 \mathrm{~mm}$ (16/64"x3/4") e redondos de 7,9 mm (20/64"). Seguiu-se o tratamento químico com os inseticidas Deltamethrin $25 \%$ e Pirimiphos-methyl $50 \%$, nas dosagens respectivas de 0,1 e $2 \mathrm{~g}$ i.a. $/ 100 \mathrm{~kg}$ de sementes. 


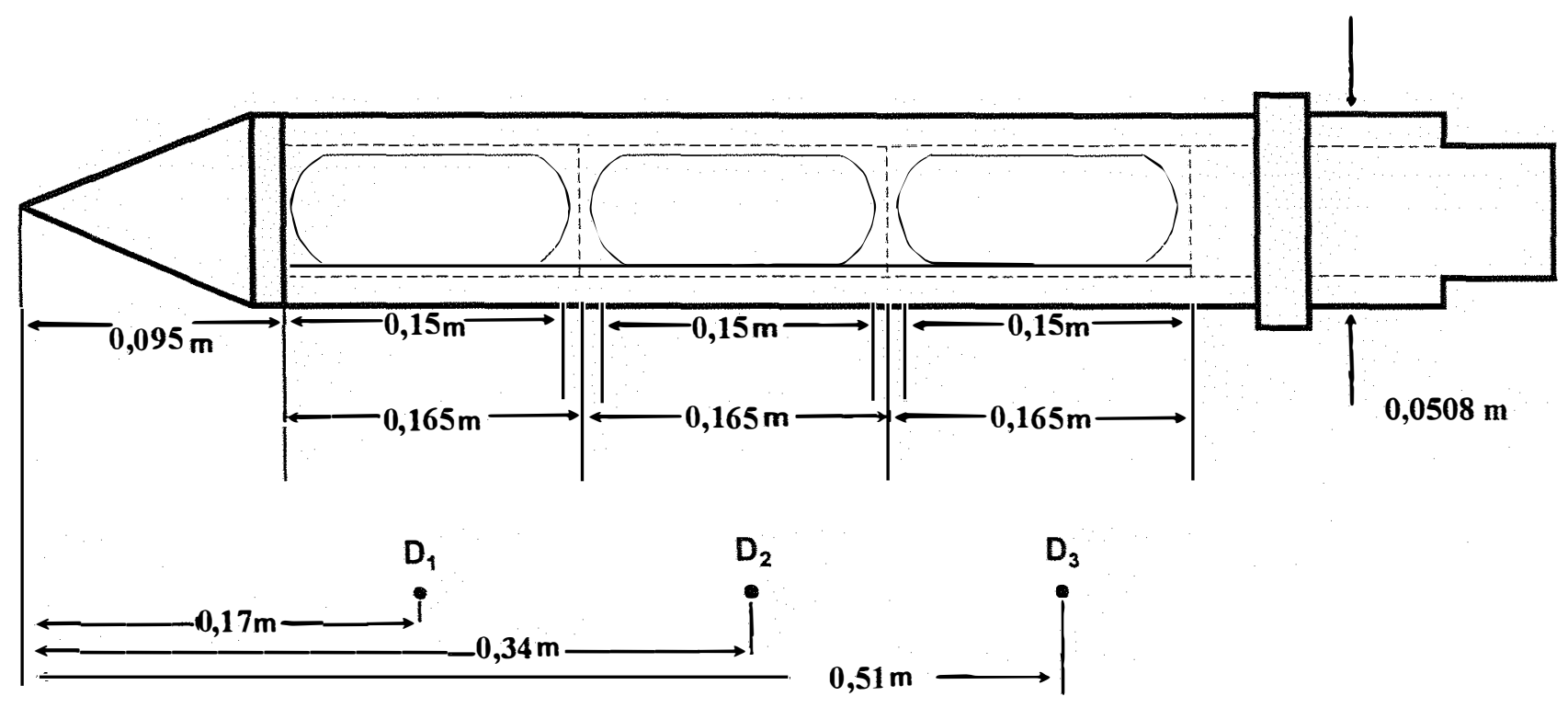

Figura 1. Esquema do corte longitudinal do amostrador duplo septado, indicando as distâncias de amostragem $D_{1}, D_{2}, D_{3}$. 


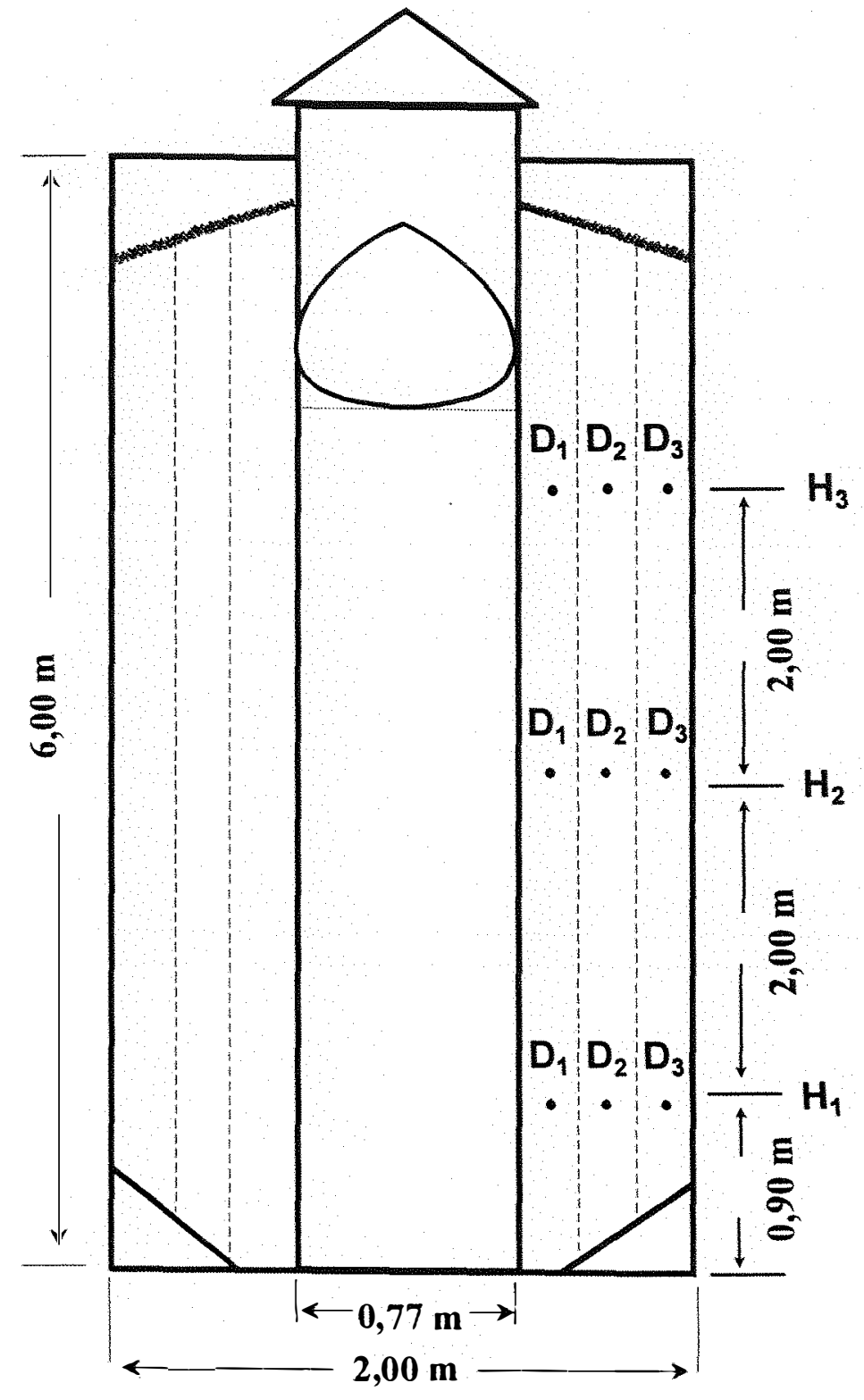

Figura 2.1.

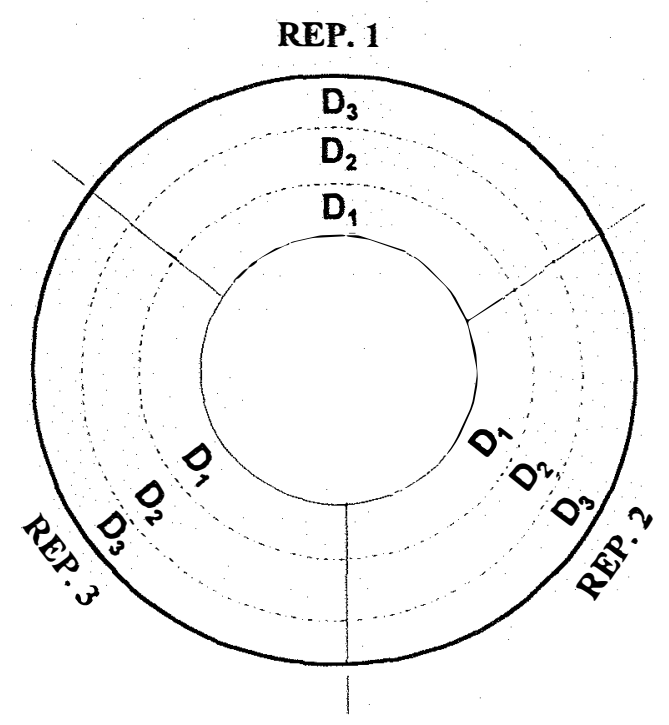

Figura 2.2.

Figuras 2.1. e 2.2. Esquemas dos cortes longitudinal (2.1) e transversal (2.2) do secador estacionário, marca ROTA mod. RC 10, indicando as distâncias de amostragem $\left(D_{1}, D_{2}, D_{3}\right)$ nas alturas $\mathrm{H}_{1}, \mathrm{H}_{2}, \mathrm{H}_{3}$. 
As amostras, em embalagens de tecido de algodão, foram mantidas, aproximadamente por 30 dias, em câmara $\left(15^{\circ} \mathrm{C}\right.$ e $60 \%$ UR) para uniformização do teor de água das sementes; a seguir, foram transferidas para armazém sem controles especiais das condições de ambiente, em momento correspondente ao início do armazenamento, permanecendo nessa condição por um período de 6 meses. No quarto mês, as sementes foram tratadas, durante 72 horas, com fosfeto de alumínio $(0.5 \mathrm{~g}$ de produto comercial $/ 100 \mathrm{~kg}$ de sementes).

\subsection{Andamento físico da secagem}

Foram obtidos os seguintes dados para cada intervalo de $1,5 \mathrm{~h}$ de secagem:

3.2.1. - Temperatura $\left({ }^{\circ} \mathrm{C}\right)$ e umidade relativa (\%) do ar ambiental: determinadas a partir de dados obtidos em psicrômetro instalado externamente ao secador;

3.2.2. - Temperatura $\left({ }^{\circ} \mathrm{C}\right)$ do ar insuflado: determinada por intermédio de termômetro analógico instalado no duto de entrada do ar quente;

3.2.3. - Umidade relativa (\%) e pressão de vapor $(\mathrm{kPa})$ do ar insuflado: calculadas a partir dos dados de temperatura e umidade absoluta do ar insuflado através de programa para determinar propriedades 
psicrométricas (Biagi \& Silva, 1990), considerando a pressão barométrica de $710 \mathrm{~mm}$ de mercúrio;

3.2.4. - Fluxo médio $\left(\mathrm{m}^{3} / \mathrm{min} . / \mathrm{t}\right)$ do ar insuflado: calculado a partir do registro da velocidade do ar com anemômetro axial, marca Airflow mod. LCA 6000 $V T$, em nove posições da seção do duto de entrada do ar, de acordo com a seguinte equação:

$$
\begin{aligned}
& F=15 \times \pi D^{2} \times V \times M^{-1} \quad \begin{array}{l}
\text { onde: } \\
F=\text { fluxo do ar }\left(\mathrm{m}^{3} / \mathrm{min} . / \mathrm{t}\right) \\
D=\text { diâmetro do duto de ar }(\mathrm{m}) \\
V=\text { velocidade do ar }(\mathrm{m} / \mathrm{s}) \\
M=\text { massa das sementes }(\mathrm{t})
\end{array}
\end{aligned}
$$

3.2.5. - Pressão estática ( $\mathrm{mm} \mathrm{ca}$ ) do ar insuflado: determinada através de manômetro em "U", marca Salcas mod. MCU, conectado a três posições equidistantes na circunferência externa da câmara de plenum da base do secador;

3.2.6. - Temperatura $\left({ }^{\circ} \mathrm{C}\right)$ da massa de sementes: foi registrada, empregando aparelho digital da marca Entag equipado com pares termelétricos, em todos os pontos de amostragem das sementes; a temperatura, referente a cada uma das três distâncias consideradas em relação ao tubo central de insuflação de ar, foi representada pela média das temperaturas obtidas nas três alturas $\left(H_{1}, H_{2}, H_{3}\right)$ correspondentes; 
3.2.7. - Variação da temperatura $\left({ }^{\circ} \mathrm{C}\right)$ na massa de sementes: representada pela diferença entre as temperaturas encontradas nas distâncias $D_{1} e$ $\mathrm{D}_{3}$;

3.2.8. - Teor (\%) de água das sementes: a partir das amostras representantes das distâncias $D_{1}, D_{2}$ e $D_{3}$, foi realizada em estufa elétrica de desidratação sem ventilação forçada, utilizando o método de estufa à $105^{\circ} \mathrm{C} \pm 3^{\circ} \mathrm{C}$, durante 24 horas, conforme a metodologia descrita nas Regras para Análise de Sementes (Brasil, 1992);

3.2.9. - Variação do teor (\%) de água na massa de sementes: indicada pela diferença entre os teores de água obtidos nas amostras de sementes relativas às distâncias $D_{1}$ e $D_{3}$;

3.2.10. - Teor (\%) de água médio ponderado da massa de sementes: a partir dos dados obtidos nas distâncias $D_{1}, D_{2}$ e $D_{3}$, foi calculada considerando a representatividade relativa de cada distância $\left(D_{1}=\right.$ $30 \% ; D_{2}=30 \% ; D_{3}=40 \%$ ) no volume ocupado pela massa de sementes;

3.2.11. - Curvas de secagem: foram determinadas, através da seleção de modelos matemáticos de melhor ajuste aos dados, relacionando o teor de água das sementes e o tempo de secagem nas três distâncias $\left(D_{1}\right.$, $D_{2}$ e $\left.D_{3}\right)$; 
3.2.12. - Velocidade média $\left(\% \mathrm{H}_{2} \mathrm{O} / \mathrm{h}\right)$ de secagem: estimou a remoção de água das sementes, nas três distâncias $\left(D_{1}, D_{2}\right.$ e $\left.D_{3}\right)$, por unidade de tempo; para tanto, foi calculada pelo quociente entre a diferença dos teores inicial e final de água das sementes e o tempo total (9 h) de secagem;

3.2.13. - Velocidade média ponderada $\left(\% \mathrm{H}_{2} \mathrm{O} / \mathrm{h}\right)$ de secagem da massa de sementes: utilizando a velocidade média de secagem encontrada em $D_{1}, D_{2}$ e $D_{3}$, foi calculada levando em conta a participação relativa de cada distância $\left(D_{1}=30 \% ; D_{2}=30 \% ; D_{3}=40 \%\right)$ no volume ocupado pela massa de sementes.

\subsection{Consequências provocadas às sementes}

Utilizando as amostras de sementes coletadas a cada $3,0 \mathrm{~h}$ de secagem nas distâncias $D_{1}, D_{2}$ e $D_{3}$, foram conduzidas as seguintes determinações no início (efeitos imediatos) e no final (efeitos latentes) do armazenamento de 6 meses:

3.3.1. - Teor (\%) de água: conduzido com metodologia similar à descrita em 3.2.8.

3.3.2. - Teste de germinação (\%): conduzido em rolo de papel toalha sob $30^{\circ} \mathrm{C}$, em 2 subamostras de 50 sementes por repetição, seguindo as demais recomendações contidas em Brasil (1992); 
3.3.3. - Teste de envelhecimento artificial (\%): executado em duas subamostras de 50 sementes por repetição, baseou-se na metodologia descrita por Marcos Filho (1994), consistindo na utilização de caixas gerbox como compartimento individual (mini-câmaras) possuindo, no seu interior, uma bandeja de tela de aço inox sobre a qual foram distribuídas as sementes; mantiveram-se as mini-câmaras a $41^{\circ} \mathrm{C}$, após a adição de $40 \mathrm{ml}$ de água em seu interior, por período de 96 horas; após esse período, as sementes foram submetidas ao teste de germinação, como o descrito em 3.3.1., com interpretação aos 4 dias após a instalação;

3.3.4. - Teste de frio (\%): conduzido com duas subamostras de 50 sementes por repetição distribuídas, à profundidade de $2-3 \mathrm{~cm}$, em caixas plásticas contendo substrato, composto de mistura areia/solo na proporção de 3:1, umedecido com água equivalente a $60 \%$ da capacidade de retenção da mistura; uma vez tampadas, as caixas foram mantidas a $10^{\circ} \mathrm{C}$ por 7 dias e, em seguida, à temperatura ambiente por igual período, quando procedeu-se a contagem do número de plântulas emersas (Cícero \& Vieira, 1994);

3.3.5. - Teste de emergência (\%) das plântulas em campo: realizado com irrigação suplementar à precipitação pluvial, foi conduzido com 2 subamostras de 50 sementes por repetição semeadas, a $5 \mathrm{~cm}$ de profundidade, em linhas de $2 \mathrm{~m}$ distanciadas de $0,30 \mathrm{~m}$ entre $\mathrm{si}$; a 
avaliação, aos 14 dias após a semeadura, considerou as plântulas emersas presentes;

3.3.6. - Teste de condutividade elétrica $(\mu \mathrm{mhos} / \mathrm{cm} / \mathrm{g})$ : quatro subamostras de 25 sementes por repetição, com massa conhecida, foram colocadas para embeber, em recipientes plásticos contendo $75 \mathrm{ml}$ de água destilada, por $24 \mathrm{~h}$ a $25^{\circ} \mathrm{C}$; seguiu-se agitação e leitura em condutivimetro (Vieira, 1994);

3.3.7. - Teste de comprimento de raiz $(\mathrm{cm})$ : realizado conforme metodologia descrita por Nakagawa (1994), consistiu na semeadura de duas subamostras de 10 sementes por repetição, sobre linha traçada longitudinalmente no terço superior de papel substrato previamente umedecido, com as radiculas direcionadas para a porção inferior do papel; os substratos, na forma de rolo, foram mantidos verticalmente em germinador, a $30^{\circ} \mathrm{C}$ em ausência de luz, para a avaliação do comprimento da raíz no quarto dia após a semeadura.

\subsection{Procedimentos estatísticos}

As curvas de secagem, representadas por equações de regressão que relacionam o teor de água das sementes com o tempo de secagem, foram obtidas pela seleção entre modelos matemáticos (polinomiais e exponenciais) adaptados a dados biológicos. 
O estudo sobre as consequências provocadas às sementes, com exceção dos dados do teor de água que não foram estatisticamente analisados, considerou, separadamente, os efeitos de distância (D) $x$ tempo de secagem (TS) e de fluxo $(F) \times$ temperatura $(T)$.

Os efeitos de distância $x$ tempo de secagem foram analisados, preliminarmente, em cada combinação $F \times T$. Constatadas diferenças aceitáveis entre valores extremos dos quadrados médios residuais, optou-se por análise conjunta, de todas as combinações $F \times T$, segundo delineamento inteiramente casualizado, em esquema fatorial com 3 repetições (Tabela 2).

Tabela 2. Esquema da análise de variância conjunta dos dados de qualidade fisiológica para distâncias e tempo de secagem.

\begin{tabular}{lc}
\hline \hline Causas da variação & Graus de liberdade \\
\hline \hline Distâncias (D) & 2 \\
Tempo de secagem (TS) & 3 \\
Interação DxTS & 6 \\
Residuo médio & 216 \\
\hline \hline
\end{tabular}

Para avaliar os efeitos de fluxo $\times$ temperatura do ar insuflado, foram analisados os valores médios, calculados para todas as combinações $D x$ TS, segundo delineamento experimental inteiramente casualizado, em esquema fatorial com 3 repetições (Tabela 3). 
Tabela 3. Esquema da análise de variância dos dados de qualidade fisiológica para fluxos e temperaturas

\begin{tabular}{lc}
\hline \hline Causas da variação & Graus de liberdade \\
\hline Fluxos (F) & 2 \\
Temperaturas $(T)$ & 2 \\
Interação FxT & 4 \\
Resíduo médio & 18 \\
\hline \hline
\end{tabular}

A comparação de médias foi efetuada, em ambos os casos, pelo teste de Tukey ao nivel de $5 \%$ de probabilidade. 


\section{RESULTADOS E DISCUSSÃO}

\subsection{Andamento físico da secagem}

Os dados do ar ambiente, ar insuflado e temperatura da massa de sementes, correspondentes à secagem estacionária conduzida sob diferentes fluxos e temperatura do ar, são apresentados nas Tabelas 4, 5 e 6.

Apesar das oscilações constatadas no ar ambiente dentro e entre tratamentos de secagem, as temperaturas do ar insuflado mantiveram-se próximas às desejadas; quando fixadas estas temperaturas, o ar insuflado apresentou variações máximas de $5,5 \%$ e de $0,7 \mathrm{kPa}$, respectivamente, entre as umidades relativas e entre as pressões de vapor. Com isso, as condições operacionais, durante as secagens, puderam ser consideradas como uniformes e isentas de variações provenientes de interferências climáticas externas ao secador.

A pressão estática cresceu, com a elevação dos fluxos de ar, apresentando valores equivalentes aos encontrados por Brandenburg et al. (1961) e Brooker et al. (1974) e inferiores aos verificados por Mclean (1980) em fluxos similares aos utilizados nesta pesquisa. 


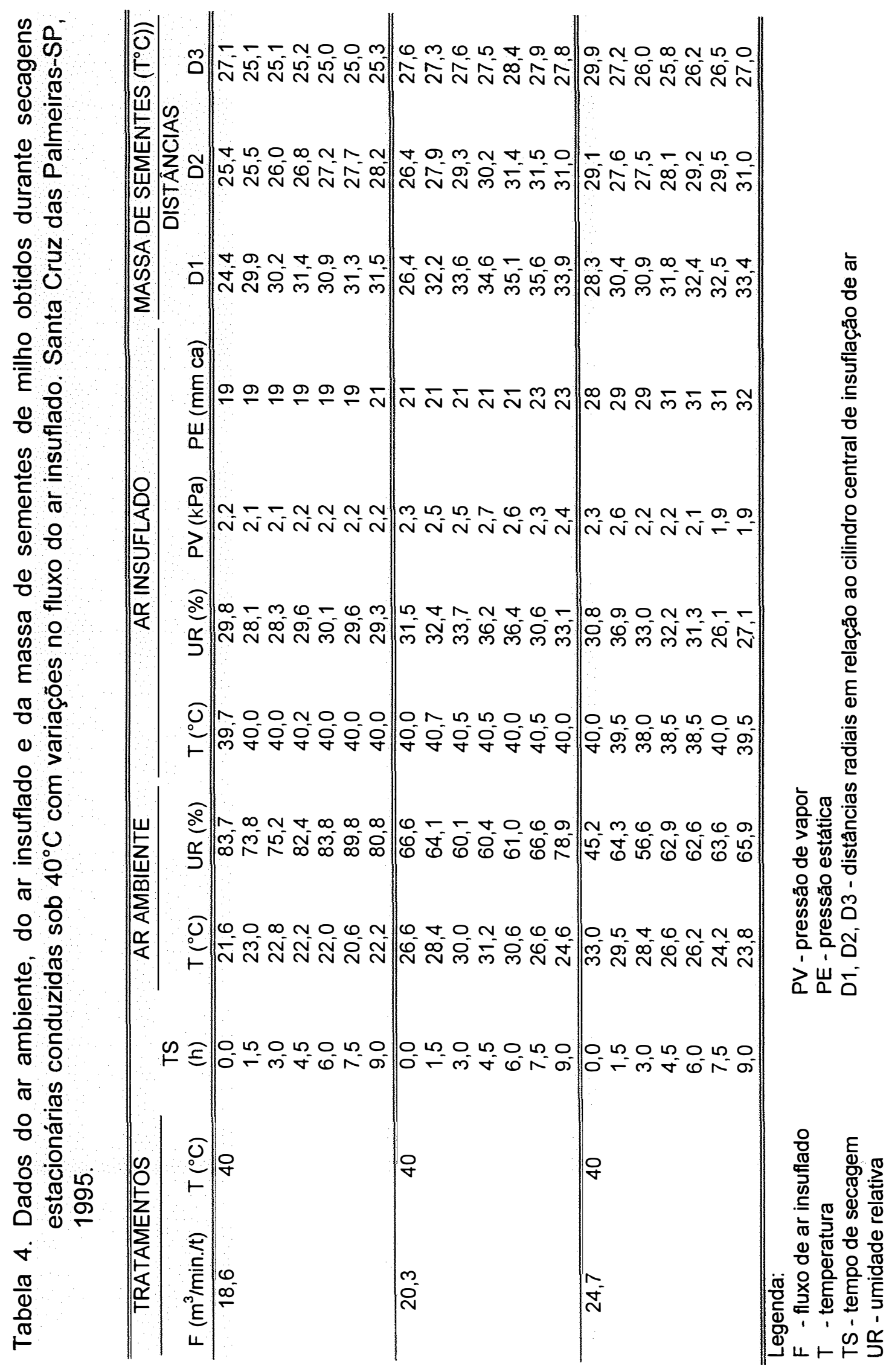




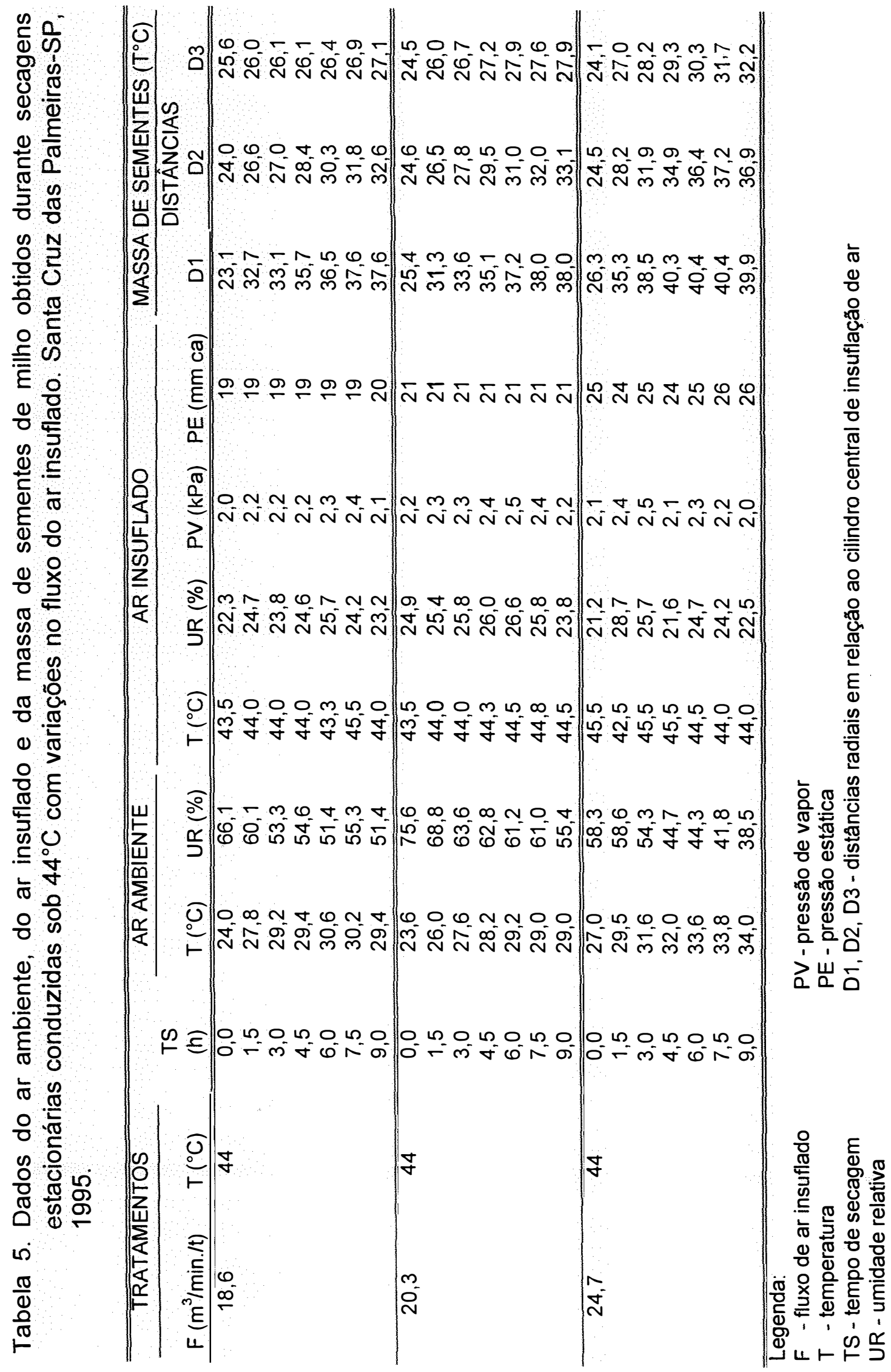




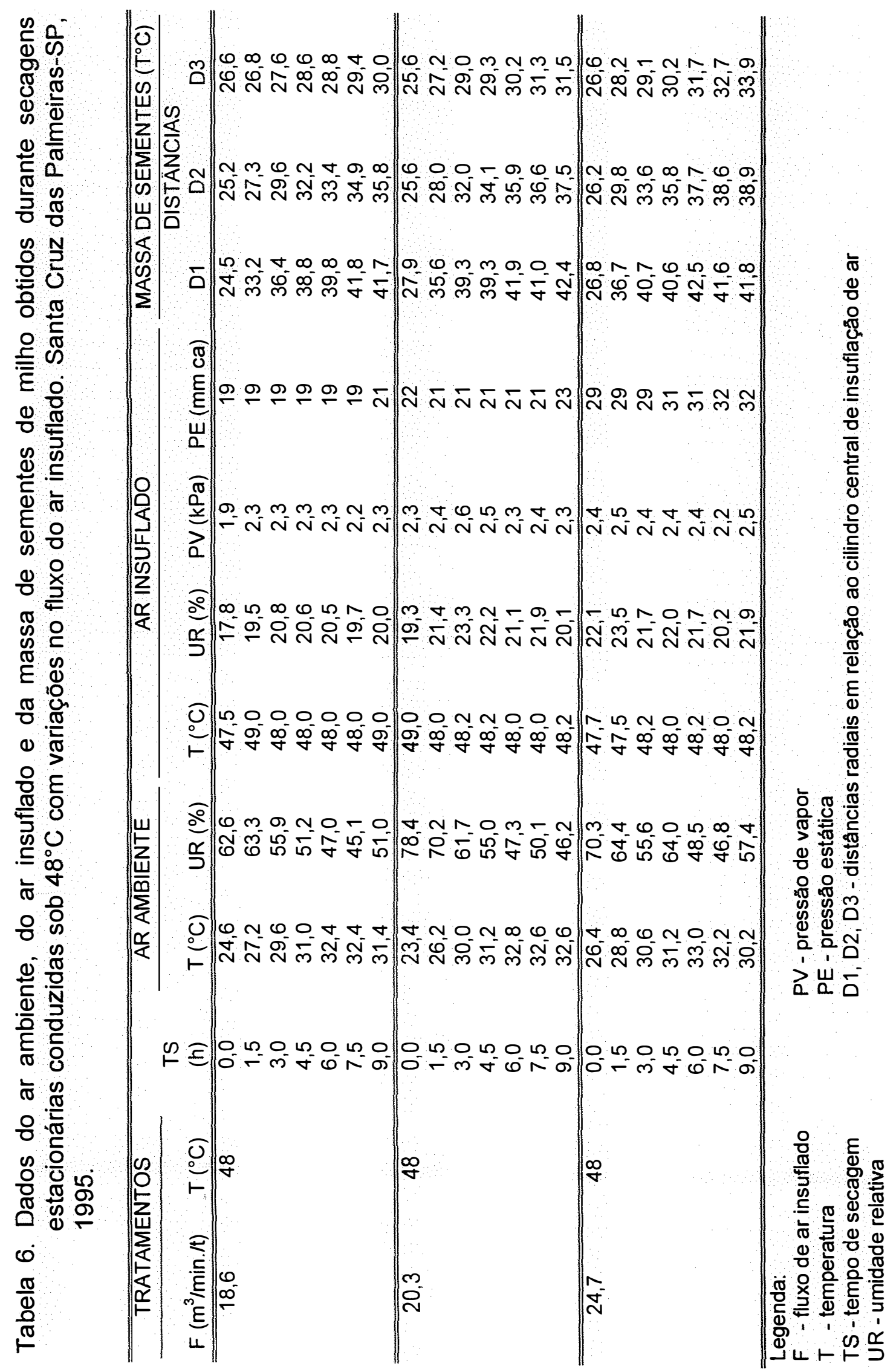


Os valores encontrados, nunca superiores a $32 \mathrm{~mm} \mathrm{ca}$, sugeriram características aerodinâmicas favoráveis do secador, proporcionadas pela reduzida espessura da massa de sementes, conforme o mencionado por Mclean (1980). Fixadas as combinações de fluxos e temperaturas, a pressão estática tendeu a se elevar com o andamento das secagens, particularmente após $6,0 \mathrm{~h}$ de operação. Considerando a existência de constância em outros fatores intervenientes, tais como espessura da massa, taxa de impurezas e características do pericarpo das sementes, o fato pode ser atribuído, provavelmente, à paulatina redução no volume dos espaços porosos (acomodação da massa), como conseqüência da redução do teor de água das sementes.

Por outro lado, o expediente metodológico adotado, para obtenção dos dados de pressão estática, revelou-se adequado na medida em que foram obtidas leituras estáveis quando o manômetro foi conectado a três pontos equidistantes na câmara de plenum, o que não aconteceu quando a conecção foi efetuada, preliminarmente, em apenas um ponto.

Os dados de temperatura da massa (Tabelas 4, 5, 6) permitiram verificar decréscimos, como os esperados, à medida em que era ampliada a distância das sementes ao cilindro central de insuflação do ar. Para cada distância, as temperaturas cresceram, com o andamento da secagem, em magnitudes que se ampliaram com a redução da distância. 
Ainda, de uma forma geral, a temperatura das sementes, na distância $D_{1}$, se estabilizou após $6,0 \mathrm{~h}$ de secagem, aproximadamente, com valores situados entre 12 e $20 \%$ abaixo da temperatura do ar insuflado. $\mathrm{Na}$ distância $D_{2}$, o tempo de secagem revelou-se insuficiente para que ocorresse a estabilização da temperatura que, por sua vez, sofreu maior elevação no transcurso da secagem com o aumento do fluxo. A temperatura das sementes, mais distantes do cilindro central $\left(D_{3}\right)$, não se alterou durante as secagens a $40^{\circ} \mathrm{C}$, independentemente dos fluxos empregados; considerando os tratamentos de 44 e $48^{\circ} \mathrm{C}$, o comportamento foi semelhante ao encontrado em $D_{2}$.

A variação entre as temperaturas da massa, em pontos diferentemente distanciados da região de injeção do ar aquecido, gera desuniformidade de secagem e, eventualmente, dificuldades na manutenção da qualidade fisiológica das sementes durante o armazenamento. Os gradientes de temperatura, entre as distâncias extremas $D_{1}$ e $D_{3}$, aumentaram, em geral, com o transcorrer da secagem, tendendo à estabilização ou redução a partir das 6,0 h de operação (Tabela 7); menores gradientes foram constatados sob $40^{\circ} \mathrm{C}$, nos três fluxos, do que a 44 e $48^{\circ} \mathrm{C}$. Nestas últimas temperaturas, o aumento do fluxo promoveu redução do gradiente.

Independentemente dos fluxos e temperaturas do ar insuflado, os gradientes de temperatura, entre $D_{1}$ e $D_{3}$, variaram de 3,2 a $12,4^{\circ} \mathrm{C}$, sendo 
inferiores aos verificados por Pasin (1991) em soja e superiores aos constatados, em arroz, por Corrêa (1981). Mclean (1980) e Pasin (1991) referem-se à ausência de efeitos de gradientes de temperatura, sobre a qualidade das sementes, promovida pela homogeneização da massa durante a descarga do secador.

Tabela 7. Diferenças $\left({ }^{\circ} \mathrm{C}\right)$ entre as temperaturas da massa de sementes de milho $\left(T^{\circ} \mathrm{C}\right.$ em $D_{1}-T^{\circ} \mathrm{C}$ em $\left.D_{3}\right)$ durante secagens estacionárias com diferentes fluxos e temperaturas do ar insuflado. Santa Cruz das Palmeiras-SP, 1995.

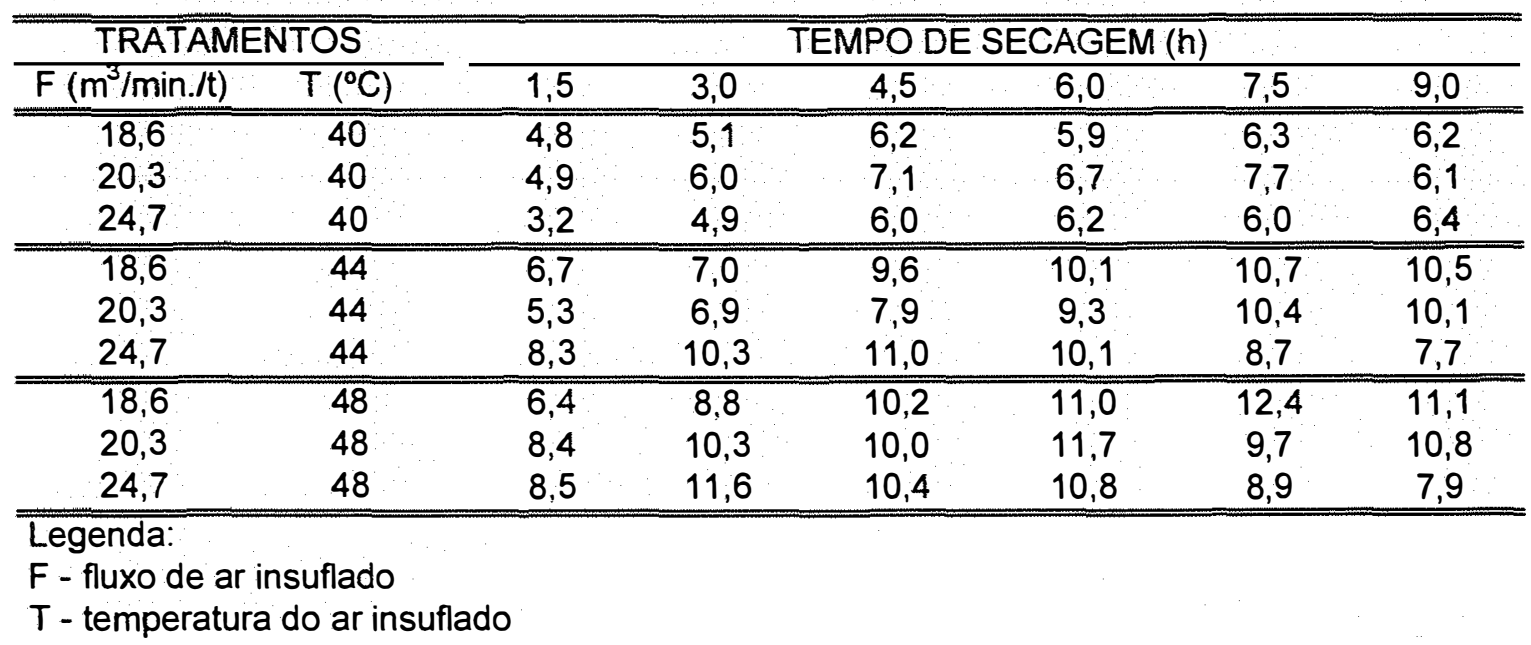

As Tabelas 8,9 e 10 indicam os dados do teor de água das sementes, nas distâncias $D_{1}, D_{2}$ e $D_{3}$, e os valores da média ponderada da massa durante as secagens. De modo generalizado, os valores obtidos refletiram os efeitos das variações nas temperaturas, atingidas pelas sementes, sobre a eficiência da secagem. Paralelamente, houve indicações consistentes de similaridade entre os valores obtidos em $D_{2}$ e os calculados para a média ponderada da massa. 
Tabela 8 . Teores (\%) de água das sementes de milho: valores obtidos nas distâncias $D_{1}, D_{2}$ e $D_{3}$ e média ponderada da massa em secagens estacionárias conduzidas sob $40^{\circ} \mathrm{C}$ com variações no fluxo do ar insuflado. Santa Cruz das Palmeiras-SP, 1995.

\begin{tabular}{|c|c|c|c|c|c|c|}
\hline \multicolumn{2}{|c|}{ TRATAMENTOS } & \multirow{2}{*}{$\begin{array}{l}\text { TS } \\
\text { (h) }\end{array}$} & \multicolumn{3}{|c|}{ DISTANNCIAS } & \multirow{2}{*}{$\begin{array}{l}\text { MEDIADA } \\
\text { MASSA }\end{array}$} \\
\hline $\mathrm{F}\left(\mathrm{m}^{3} / \mathrm{min} / \mathrm{t}\right)$ & $T\left({ }^{\circ} \mathrm{C}\right)$ & & $D_{1}$ & $D_{2}$ & $D_{3}$ & \\
\hline \multirow[t]{7}{*}{18,6} & 40 & 0,0 & 16,6 & 16,6 & 16,7 & 16,6 \\
\hline & & 1,5 & 15,6 & 16,2 & 16.4 & 16,1 \\
\hline & & 3,0 & 14,7 & 16,3 & 16,5 & 15,9 \\
\hline & & 4,5 & 14,3 & 16,2 & 16,7 & 15,8 \\
\hline & & 6,0 & 13.5 & 15,4 & 16,3 & 15,2 \\
\hline & & 7,5 & 13,4 & 15,2 & 16,4 & 15,1 \\
\hline & & 9,0 & 13,1 & 14,7 & 16,2 & 14,8 \\
\hline \multirow[t]{7}{*}{20,3} & 40 & $\overline{0,0}$ & 15,8 & 15,9 & 15,8 & 15,8 \\
\hline & & 1,5 & 15,0 & 15,6 & 15,6 & 15,4 \\
\hline & & 3,0 & 14,4 & 15,6 & 15,7 & 15,3 \\
\hline & & 4,5 & 13,8 & 15,0 & 16,0 & 15,0 \\
\hline & & 6,0 & 12,9 & 14,6 & 15,6 & 14,5 \\
\hline & & 7,5 & 12,5 & 14,3 & 15,5 & 14,2 \\
\hline & & 9,0 & 12,4 & 14,0 & 15,2 & 14,0 \\
\hline \multirow[t]{7}{*}{24,7} & 40 & 0,0 & 15,7 & 15,8 & 15,8 & 15,8 \\
\hline & & 1,5 & 14,8 & 15,6 & 15,6 & 15,4 \\
\hline & & 3,0 & 13,7 & 15,1 & 15,9 & 15,0 \\
\hline & & 4,5 & 13,3 & 14,8 & 15,6 & 14,7 \\
\hline & & 6,0 & 12,2 & 13,7 & 15,1 & 13,8 \\
\hline & & 7,5 & 12,4 & 13,8 & 15,0 & 13,9 \\
\hline & & 9,0 & 11,1 & 12,9 & 13,9 & 12,8 \\
\hline
\end{tabular}

Legenda:

$F$ - fluxo de ar insuflado

$T$ - temperatura do ar insuflado

TS - tempo de secagem 
Tabela 9. Teores (\%) de água das sementes de milho: valores obtidos nas distâncias $D_{1}, D_{2}$ e $D_{3}$ e média ponderada da massa em secagens estacionárias conduzidas sob $44^{\circ} \mathrm{C}$ com variações no fluxo do ar insuflado. Santa Cruz das Palmeiras-SP, 1995.

\begin{tabular}{|c|c|c|c|c|c|c|}
\hline \multicolumn{2}{|c|}{ TRATAMENTOS } & \multirow{2}{*}{$\begin{array}{l}\text { TS } \\
\text { (h) }\end{array}$} & \multicolumn{3}{|c|}{ DISTÁNCIAS } & \multirow{2}{*}{$\begin{array}{c}\text { MÉDIA DA } \\
\text { MASSA }\end{array}$} \\
\hline $\mathrm{F}\left(\mathrm{m}^{3} / \mathrm{min} / \mathrm{t}\right)$ & $\mathrm{T}\left({ }^{\circ} \mathrm{C}\right)$ & & $D_{1}$ & $D_{2}$ & $D_{3}$ & \\
\hline \multirow[t]{7}{*}{18,6} & 44 & $\overline{0,0}$ & $\overline{17,4}$ & $\overline{17,4}$ & 17,3 & 17,4 \\
\hline & & 1,5 & 16,0 & 16,9 & 17,0 & 16,7 \\
\hline & & 3,0 & 15,0 & 16,8 & 17,1 & 16,4 \\
\hline & & 4,5 & 14,1 & 16,6 & 17,2 & 16,1 \\
\hline & & 6,0 & 13,3 & 15,8 & 16,9 & 15,5 \\
\hline & & 7,5 & 13,0 & 15,6 & 17,1 & 15,4 \\
\hline & & 9,0 & 12,2 & 14,8 & 16,6 & 14,7 \\
\hline \multirow[t]{7}{*}{$\overline{20,3}$} & $\overline{444}$ & 0,0 & 17,3 & 17,3 & 17,2 & 17,3 \\
\hline & & 1,5 & 16,1 & 17,1 & 17,4 & 16,9 \\
\hline & & 3,0 & 15,0 & 16,9 & 17,3 & 16,5 \\
\hline & & 4,5 & 14,2 & 16,7 & 17,3 & 16,2 \\
\hline & & 6,0 & 13,6 & 16,3 & 17,2 & 15,9 \\
\hline & & 7,5 & 12,4 & 15,7 & 17,0 & 15,2 \\
\hline & & 9,0 & 12,0 & 14,8 & 16,7 & 14,7 \\
\hline \multirow[t]{7}{*}{24,7} & 44 & 0,0 & 15,8 & 15,8 & 15,8 & 45,8 \\
\hline & & 1,5 & 14,2 & 15,7 & 15,9 & 15,3 \\
\hline & & 3,0 & 13,0 & 15,2 & 15,9 & 14,8 \\
\hline & & 4,5 & 12,0 & 14,2 & 15,7 & 14,1 \\
\hline & & 6,0 & 11,4 & 13,4 & 14,9 & 13,4 \\
\hline & & 7,5 & 10,8 & 12,6 & 14,5 & 12,8 \\
\hline & & 9,0 & 9,3 & 11,6 & 12,1 & 11,1 \\
\hline
\end{tabular}

\footnotetext{
Legenda:

$F$ - fluxo de ar insuflado

$T$ - temperatura do ar insuflado

TS - tempo de secagem
} 
Tabela 10. Teores (\%) de água das sementes de milho: valores obtidos nas distâncias $D_{1}, D_{2}$ e $D_{3}$ e média ponderada da massa em secagens estacionárias conduzidas sob $48^{\circ} \mathrm{C}$ com variações no fluxo do ar insuflado. Santa Cruz das Palmeiras-SP, 1995.

\begin{tabular}{|c|c|c|c|c|c|c|}
\hline \multicolumn{2}{|c|}{ TRATAMENTOS } & \multirow{2}{*}{$\begin{array}{l}\text { TS } \\
\text { (h) }\end{array}$} & \multicolumn{3}{|c|}{ DISTÁNCIAS } & \multirow{2}{*}{$\begin{array}{l}\text { MEDIA DA } \\
\text { MASSA }\end{array}$} \\
\hline $\mathrm{F}\left(\mathrm{m}^{3} / \mathrm{min} . / \mathrm{t}\right)$ & $\mathrm{T}\left({ }^{\circ} \mathrm{C}\right)$ & & $D_{1}$ & $\mathrm{D}_{2}$ & $D_{3}$ & \\
\hline \multirow[t]{7}{*}{18,6} & 48 & 0,0 & 16,2 & 16,4 & 16,4 & 16,3 \\
\hline & & 1,5 & 14,9 & 15,8 & 16,0 & 15,6 \\
\hline & & 3,0 & 13,8 & 15,8 & 16,2 & 15,0 \\
\hline & & 4,5 & 13,1 & 15,5 & 16,4 & 15,1 \\
\hline & & 6,0 & 12,0 & 14,3 & 16,1 & 14,3 \\
\hline & & 7,5 & 11,5 & 13,9 & 15,9 & 14,0 \\
\hline & & 9,0 & 11.4 & 13,3 & 15,3 & 13,5 \\
\hline \multirow[t]{7}{*}{20,3} & 48 & 0,0 & 15,7 & 15,6 & 15,7 & 15.7 \\
\hline & & 1,5 & 14,0 & 15,5 & 15,7 & 15,1 \\
\hline & & 3,0 & 12,9 & 15,0 & 15,6 & 14,6 \\
\hline & & 4,5 & 11,8 & 14,1 & 15,4 & 13,9 \\
\hline & & 6,0 & 10,9 & 13,2 & 15,2 & 13,3 \\
\hline & & 7,5 & 10,6 & 12,9 & 15.0 & 13,0 \\
\hline & & 9,0 & 10,5 & 12,2 & 14,4 & 12,6 \\
\hline \multirow[t]{7}{*}{24,7} & 48 & 0,0 & 15,8 & 16,0 & 16,0 & 15,9 \\
\hline & & 1,5 & 14,4 & 15,6 & 15,8 & 15,3 \\
\hline & & 3,0 & 13,2 & 15,0 & 16,0 & 14,9 \\
\hline & & 4,5 & 12,2 & 14,0 & 15,6 & 14,1 \\
\hline & & 6,0 & 11,6 & 13,0 & 14,6 & 13,2 \\
\hline & & 7,5 & 11,1 & 12,4 & 14,3 & 12,7 \\
\hline & & 9,0 & 11,1 & 12,5 & 13,7 & 12,6 \\
\hline
\end{tabular}

Legenda:

$F$ - fluxo de ar insuflado

$T$ - temperatura do ar insuflado

TS - tempo de secagem 
Independentemente dos fluxos e das temperaturas do ar insuflado, a secagem ocorreu, como o esperado, no sentido de $D_{1}$ para $D_{3}$. Por este motivo, as diferenças entre estes pontos (Tabela 11) tenderam à ampliação com o andamento do processo; contudo, à medida em que foram elevados os fluxos e as temperaturas do ar insuflado, os gradientes foram reduzidos após $9,0 \mathrm{~h}$ de secagem.

Tabela 11. Diferenças (\%) entre os teores de água das sementes de milho $\left(\% \mathrm{H}_{2} \mathrm{O}\right.$ em $\mathrm{D}_{3}-\% \mathrm{H}_{2} \mathrm{O}$ em $\left.\mathrm{D}_{1}\right)$ durante secagens estacionárias conduzidas com diferentes fluxos e temperaturas do ar insuflado. Santa Cruz das Palmeiras-SP, 1995.

\begin{tabular}{|c|c|c|c|c|c|c|c|}
\hline \multicolumn{2}{|c|}{ TRATAMENTOS } & \multicolumn{6}{|c|}{ TEMPO DE SECAGEM (h) } \\
\hline $\mathrm{F}\left(\mathrm{m}^{3} / \mathrm{min} . / \mathrm{t}\right)$ & $\mathrm{T}\left({ }^{\circ} \mathrm{C}\right)$ & 1,5 & 3,0 & 4,5 & 6,0 & 7,5 & 9,0 \\
\hline 18,6 & 40 & 0,8 & 1,8 & $\overline{2,4}$ & 2,8 & 3,0 & 3,1 \\
\hline 20,3 & 40 & 0,6 & 1,3 & 2,2 & 2,7 & 3,0 & 2,8 \\
\hline 24,7 & 40 & 0,8 & 2,2 & 2,3 & 2,9 & 2,6 & 2,8 \\
\hline$\overline{18,6}$ & $\overline{44}$ & 1,0 & 2,1 & 3,1 & 3,6 & $\overline{4,1}$ & $\overline{4,4}$ \\
\hline 20,3 & 44 & 1,3 & 2,3 & 3,1 & 3,6 & 4,6 & 4,7 \\
\hline 24,7 & 44 & 1,7 & 2,9 & 3,7 & 3,5 & 3,7 & 2,8 \\
\hline 18,6 & 48 & $\overline{1,1}$ & $\overline{2,4}$ & 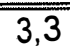 & 4,1 & $\overline{4,4}$ & $\overline{3,9}$ \\
\hline 20,3 & 48 & 1,7 & 2,7 & 3.6 & 4,3 & 4,4 & 3,9 \\
\hline 24,7 & 48 & 1,4 & 2,8 & 3,4 & 3,0 & 3,3 & 2,6 \\
\hline
\end{tabular}

As elevações de fluxos e de temperaturas agiram, isolada e conjuntamente, na aceleração da retirada de água das sementes em todas as distâncias (Tabelas $8,9,10$ ). No entanto, quando comparados, o aumento do fluxo conduziu a maiores velocidades de secagem do que o aumento da temperatura, fato especialmente verificável na distância $D_{3}$ (Tabela 12) que, 
como o observado, sofreu reduzida interferência do calor, transportado pelo ar insuflado, em sua temperatura (Tabelas $4,5,6$ ).

Da mesma forma que o verificado para o teor de água (Tabelas $8,9,10)$, a distância $D_{2}$ representou o comportamento da velocidade média de secagem da massa (Tabela 12); estes fatos sugerem que amostragens, no ponto intermediário de espessura da massa, podem permitir, satisfatoriamente, o acompanhamento da evolução média do processo de secagem.

Tabela 12. Velocidade de secagem $\left(\% \mathrm{H}_{2} \mathrm{O} / \mathrm{h}\right)$ das sementes de milho: valores obtidos nas distâncias $D_{1}, D_{2}$ e $D_{3}$ e média ponderada da massa, após secagens estacionárias de $9,0 \mathrm{~h}$, conduzidas com diferentes fluxos e temperaturas do ar insuflado. Santa Cruz das PalmeirasSP, 1995.

\begin{tabular}{|c|c|c|c|c|c|}
\hline \multicolumn{2}{|c|}{ TRATAMENTOS } & \multicolumn{3}{|c|}{ DISTANNCIAS } & \multirow{2}{*}{$\begin{array}{l}\text { MEDIA DA } \\
\text { MASSA }\end{array}$} \\
\hline $\mathrm{F}\left(\mathrm{m}^{3} / \mathrm{min} . / \mathrm{t}\right)$ & $T\left({ }^{\circ} \mathrm{C}\right)$ & $D_{1}$ & $D_{2}$ & $D_{3}$ & \\
\hline 18,6 & 40 & 0,39 & 0,21 & 0,06 & 0,20 \\
\hline 20,3 & 40 & 0,38 & 0,21 & 0,07 & 0,20 \\
\hline 24,7 & 40 & 0,51 & 0,32 & 0,21 & 0,33 \\
\hline$\overline{18,6}$ & $\overline{44}$ & $\overline{0.58}$ & 0,29 & 0,08 & $\overline{0,29}$ \\
\hline 20,3 & 44 & 0,59 & 0.28 & 0,05 & 0,28 \\
\hline 24,7 & 44 & 0,72 & 0,47 & 0,41 & 0,52 \\
\hline 18,6 & 48 & 0,53 & 0,34 & 0,12 & 0,31 \\
\hline 20,3 & 48 & 0,58 & 0,38 & 0,14 & 0,34 \\
\hline 24,7 & 48 & 0,52 & 0,39 & 0,25 & 0,37 \\
\hline
\end{tabular}

As equações de regressão, relacionadas ao comportamento do teor de água das sementes durante a secagem, acham-se apresentadas nas Tabelas 13, 14 e 15 e nas Figuras 3, 4 e 5. 
Apesar de invariavelmente significativas e, portanto, devidamente ajustadas aos dados experimentais, as equações apresentaram, em $D_{3}$, particularidades relacionadas aos valores obtidos para os coeficientes de determinação. Nestes casos, a baixa capacidade de explicação do fenômeno $\left(R^{2}=0,43\right)$, encontrada na equação de $D_{3}$ para os menores fluxo $\left(18,6 \mathrm{~m}^{3} / \mathrm{min} . / \mathrm{t}\right)$ e temperatura $\left(40^{\circ} \mathrm{C}\right)$, foi sendo ampliada à medida em que os fluxos ou as temperaturas eram aumentados. Este fato, aparentemente, associa-se à baixa variação entre os dados coletados em $D_{3}$ que, conforme o constatado (Tabelas $8,9,10$ ), não sugeriram a plena chegada da frente de secagem durante o periodo operacional de $9,0 \mathrm{~h}$, adotado experimentalmente.

Conforme alguns autores (Boyd et al., 1974; Zimmer, 1989; Paula, 1992), o deslocamento da frente de secagem apresenta relação direta com o fluxo de ar empregado e, por conseqüência, com a velocidade de secagem. Houve, à temperatura de $40^{\circ} \mathrm{C}$, menor eficiência dos fluxos de $18,6 \mathrm{e}$ $20,3 \mathrm{~m}^{3} / \mathrm{min} . / \mathrm{t}$, para realizar remoção satisfatória de água da massa, em relação à verificada no fluxo de $24,7 \mathrm{~m}^{3} / \mathrm{min}$./t que, por sua vez, promoveu decréscimo linear do teor de água das sementes, situadas em $D_{1}$ e $D_{2}$ (Tabela 13 e Figura 3), em concordância com os resultados obtidos por Luz (1986), Bounous (1986), Vega (1989) e Villela (1991) ao utilizarem método intermitente de fornecimento do calor à massa. 


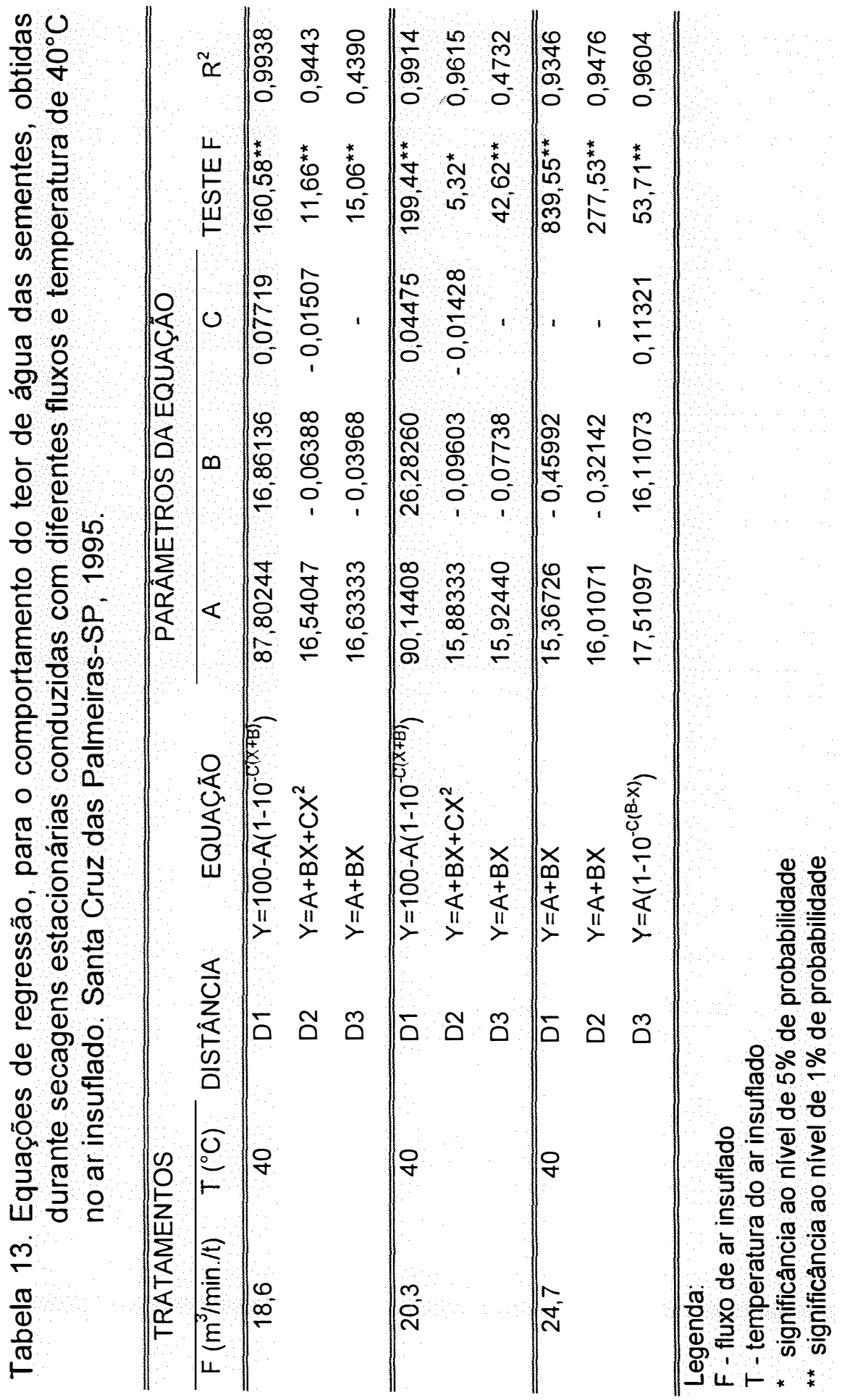




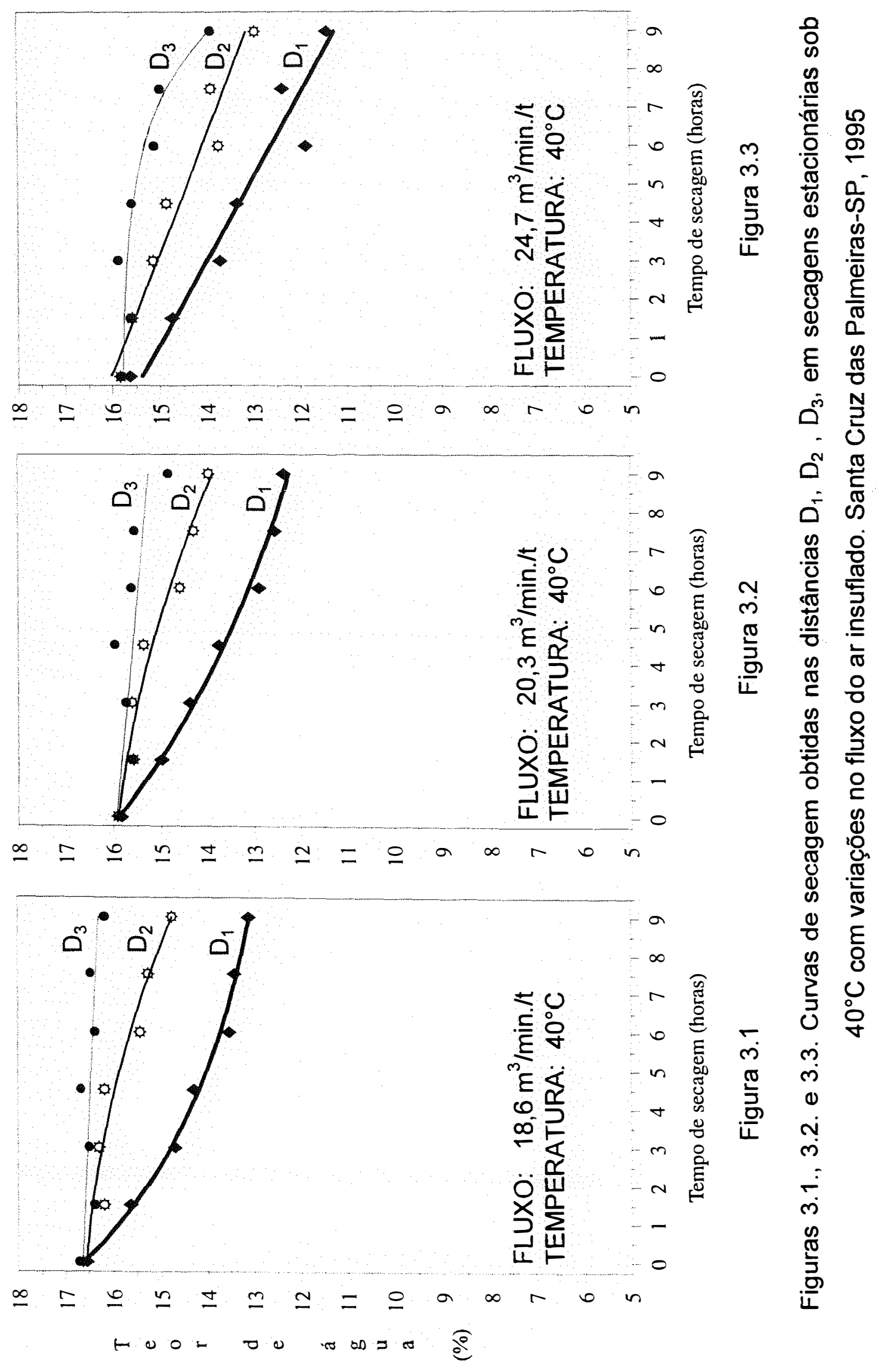


De acordo com a Tabela 14 e a Figura 4, o teor de água das sementes, independentemente das distâncias, decresceu linearmente no decurso da secagem estacionária a $44^{\circ} \mathrm{C}$ com fluxo de $18,6 \mathrm{~m}^{3} / \mathrm{min} . / \mathrm{t}$; contudo, a intensidade da secagem, conforme mostram as inclinações das curvas, foi sendo reduzida com a ampliação da distância das sementes ao tubo central de insuflação ao ponto de, em $D_{3}$, ficar caracterizada a limitada capacidade do tratamento para realizar secagem, em toda a extensão da massa, conforme o evidenciado nas médias ponderadas indicadas na Tabela 9.

Apesar de mais eficiente em $D_{1}$ e $D_{2}$, o fluxo de $20,3 \mathrm{~m}^{3} / \mathrm{min} . / \mathrm{t}$ manteve a incapacidade de possibilitar que a frente de secagem atingisse $D_{3}$. Todavia, o fluxo de $24,7 \mathrm{~m}^{3} / \mathrm{min}$. $/ \mathrm{t}$, a partir de $4,5 \mathrm{~h}$ operacionais, permitiu que as sementes da distância $D_{3}$ tivessem acentuada a perda de água, momento que pode ser considerado como referência de chegada da frente de secagem e de intercâmbio efetivo de energia e água entre as sementes e o ar insuflado. Embora, neste caso, a temperatura das sementes não tenha se alterado de modo pronunciado (Tabela 5), o fluxo de ar foi o suficiente para levar a frente de secagem à referida posição, fazendo com que o grau de umidade das sementes atingisse $12,1 \%$ (Tabela 9 ). 


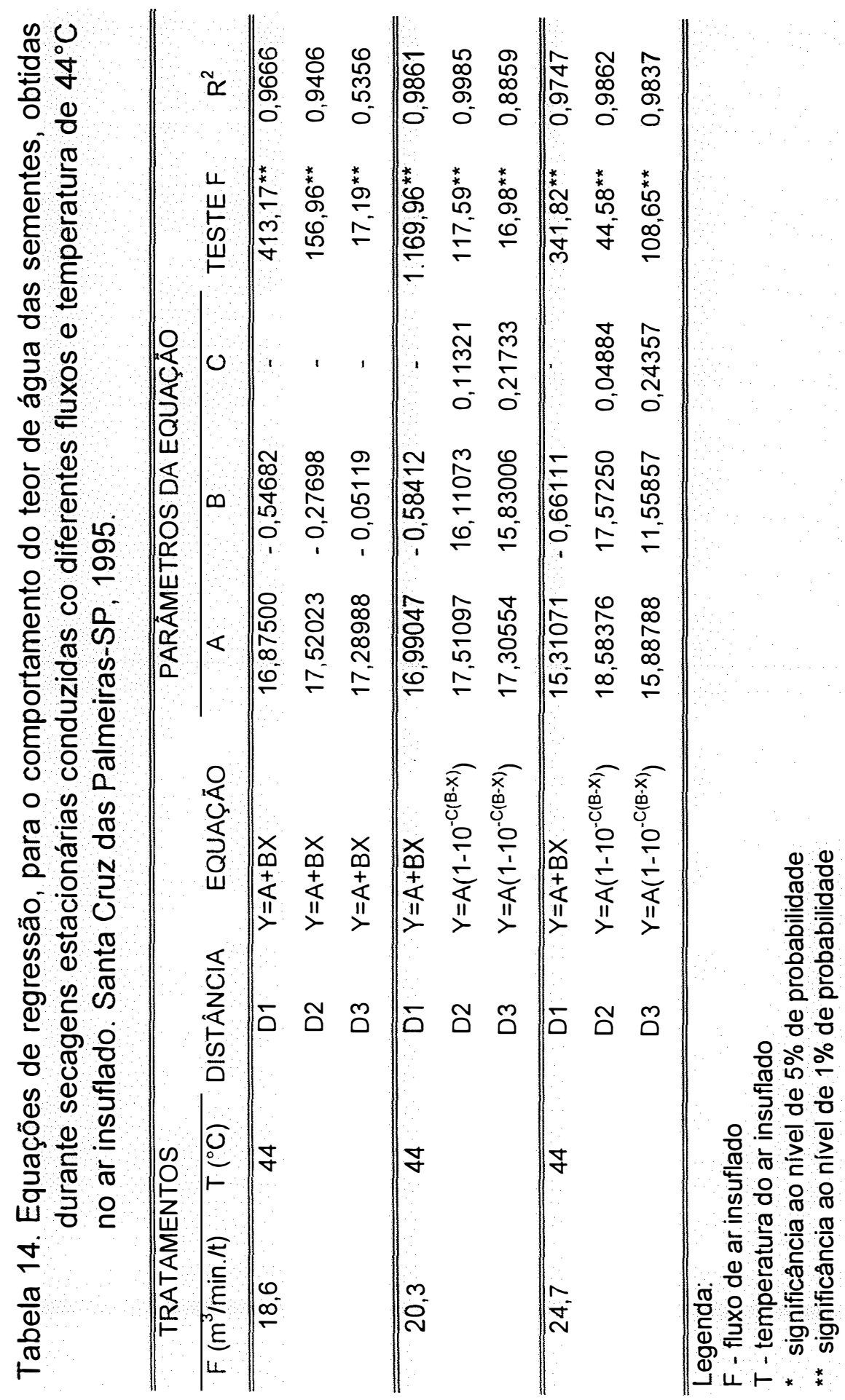




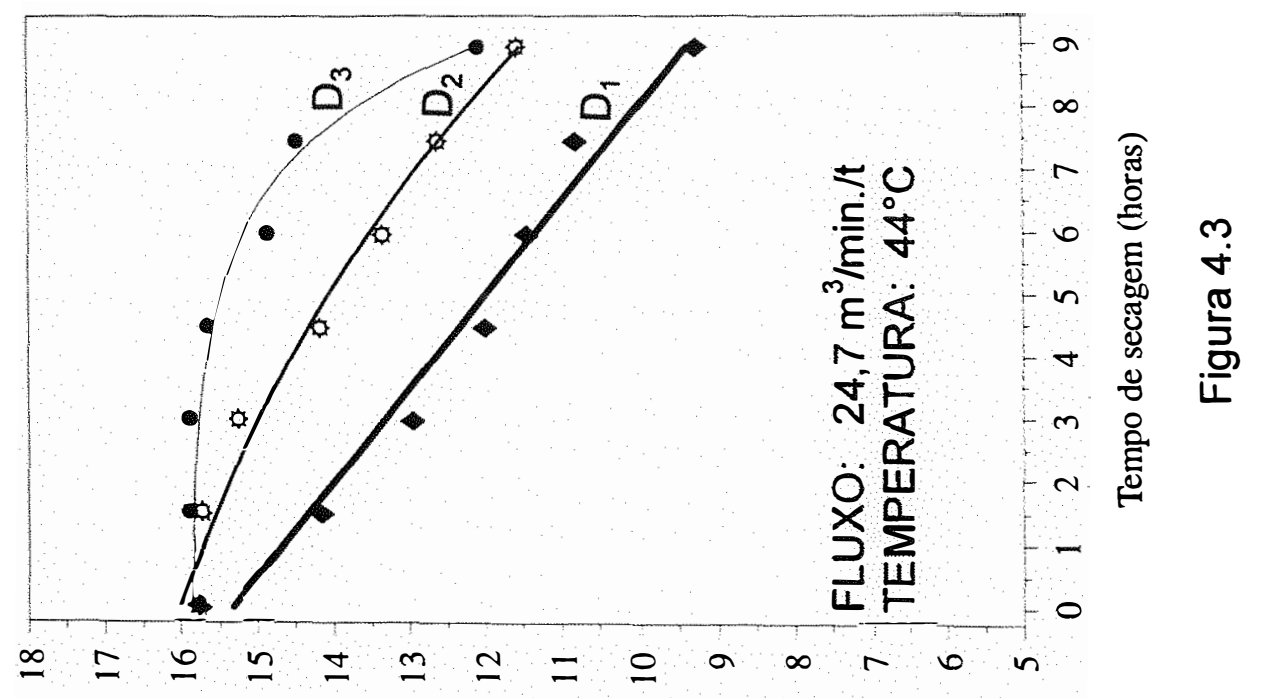

응

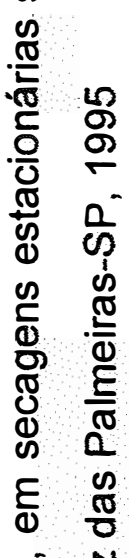

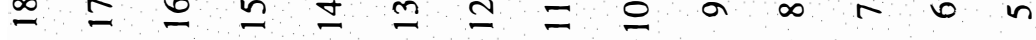

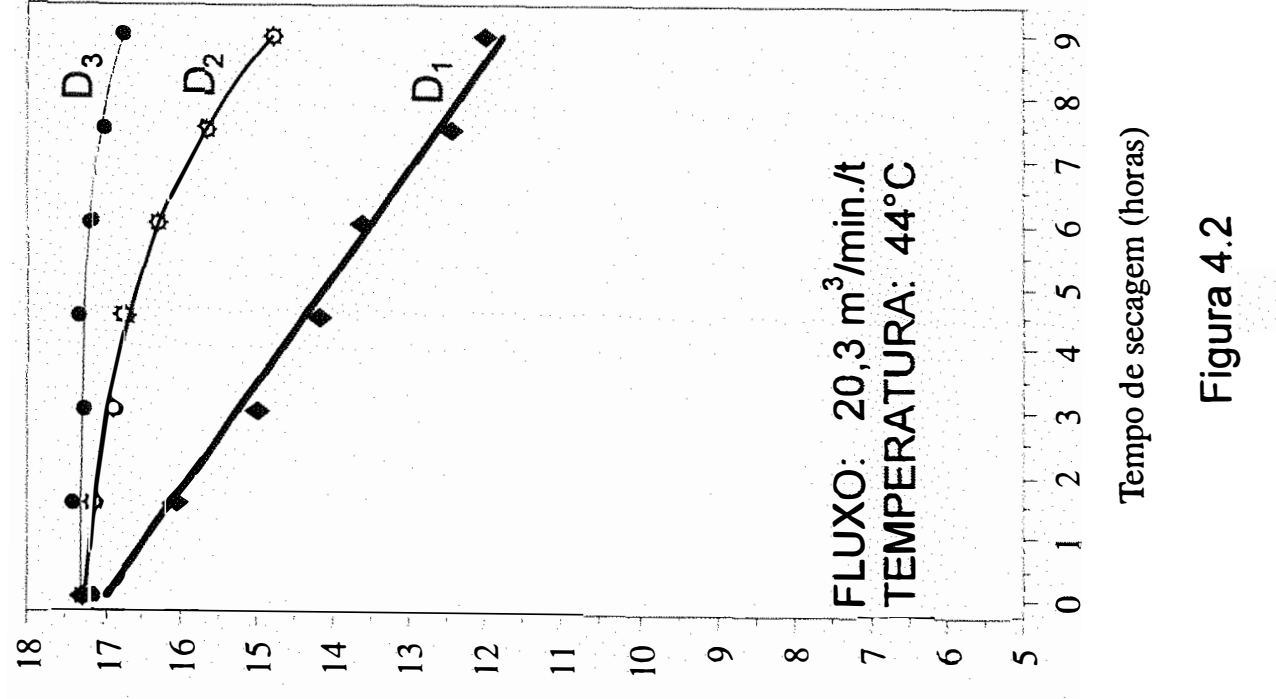

$=\frac{\pi}{\pi}$

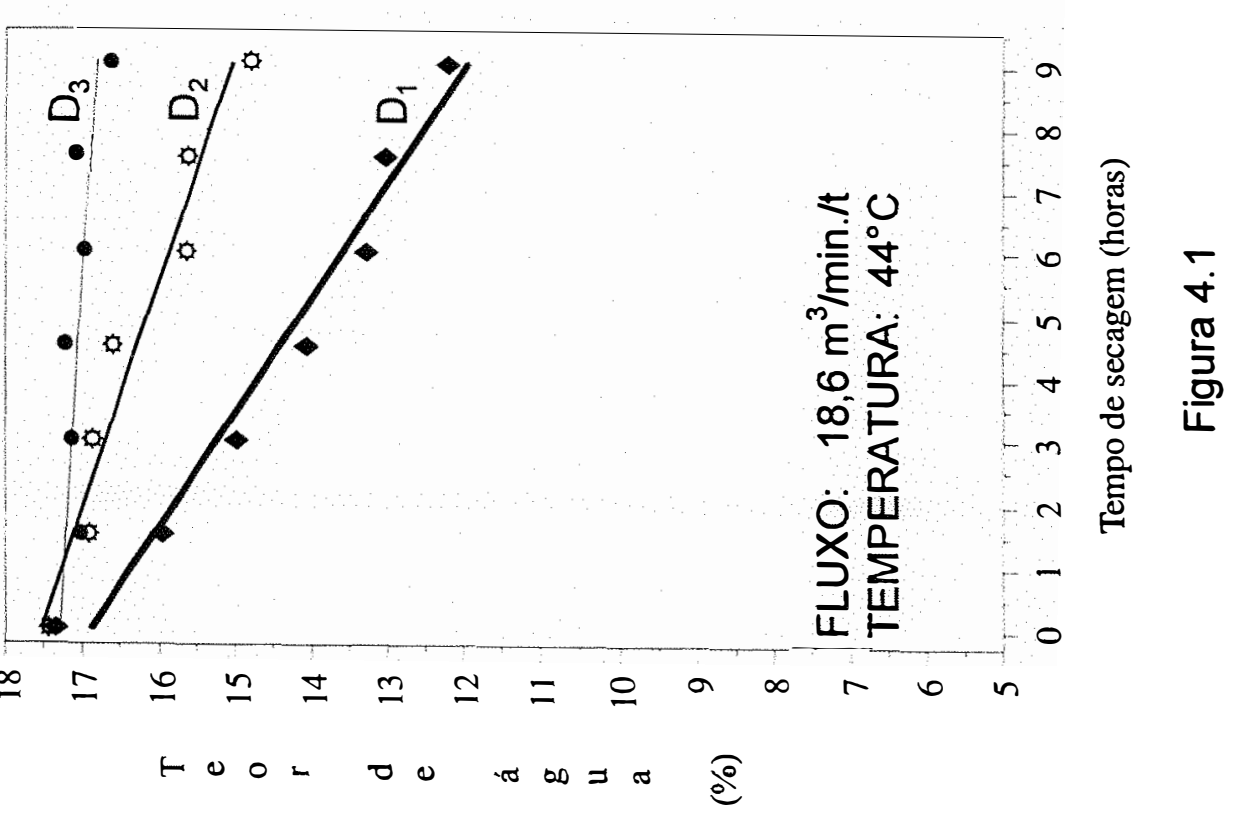

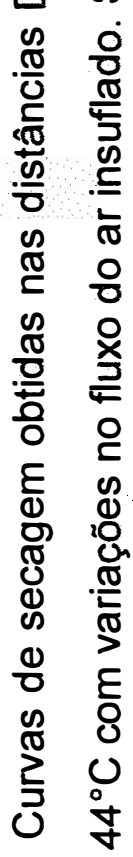

?

0

实

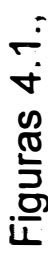


Considerando a temperatura de $48^{\circ} \mathrm{C}$ (Tabela 15, Figura 5), o fluxo de $18,6 \mathrm{~m}^{3} / \mathrm{min} . / \mathrm{t}$, pouco eficiente quando empregado em temperaturas inferiores, permitiu, em $D_{1}$. que houvesse ocorrência suficiente de evaporação para secar as sementes até $11,4 \%$ de água (Tabela 10). A perda de água das sementes, na distância $D_{2}$, acentuou-se a partir de $4,5 \mathrm{~h}$ de secagem, quando, provavelmente, houve a chegada da frente de secagem que, ao final do processo, reduziu o teor de água para $13,3 \%$ (Tabela 10 ). Na distância $D_{3} \circ$ teor de água passou a apresentar redução, somente, a partir de $7,5 \mathrm{~h}$ de operação; a ocorrência sugeriu incapacidade da frente de secagem chegar à essa posição e, ao mesmo tempo, justifica o teor de água de 15,3\% (Tabela 10) atingido ao final da secagem. Dessa forma, apesar de entendida como elevada, a temperatura de $48^{\circ} \mathrm{C}$, conjugada com o fluxo de $18,6 \mathrm{~m}^{3} / \mathrm{min} . / \mathrm{t}$, não possibilitou secagem adequada, principalmente, na região mais distanciada da fonte de ar aquecido.

Considerando o fluxo de $20,3 \mathrm{~m}^{3} / \mathrm{min}$. $/ \mathrm{t}$, sob $48^{\circ} \mathrm{C}$, verificou-se em $D_{1}$, desde o início do processo, elevada capacidade de secagem que, ao final de $9,0 \mathrm{~h}$, reduziu o teor de água das sementes para $10,5 \%$. Na distância $D_{2}$, os valores do teor de água indicaram queda mais significativa a partir de 3,0 $\mathrm{h}$ de secagem quando, provavelmente, a frente de secagem atingiu essa posição; com isso, o tratamento permitiu que as sementes apresentassem $12,2 \%$ de água ao término das $9,0 \mathrm{~h}$ do processo. 


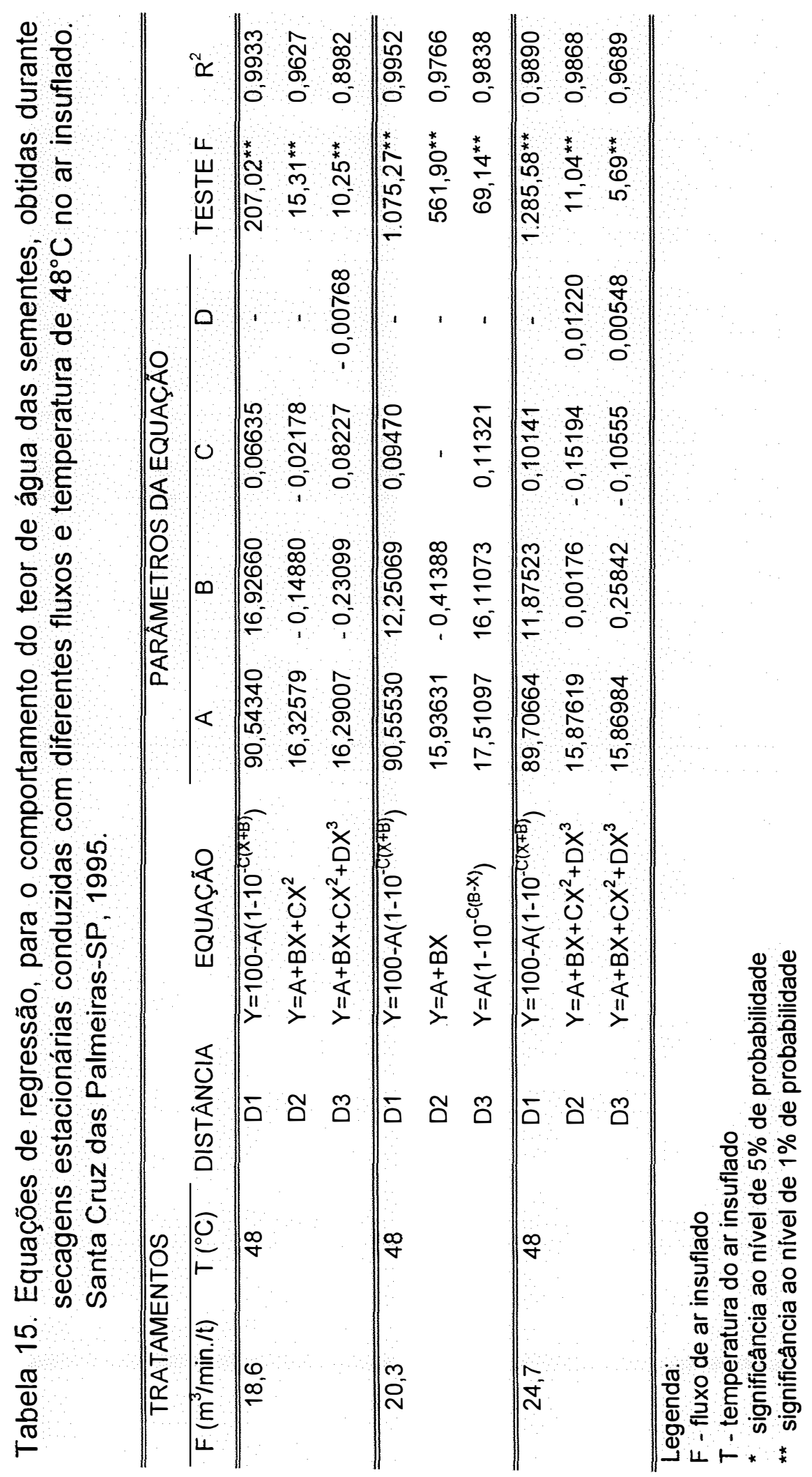



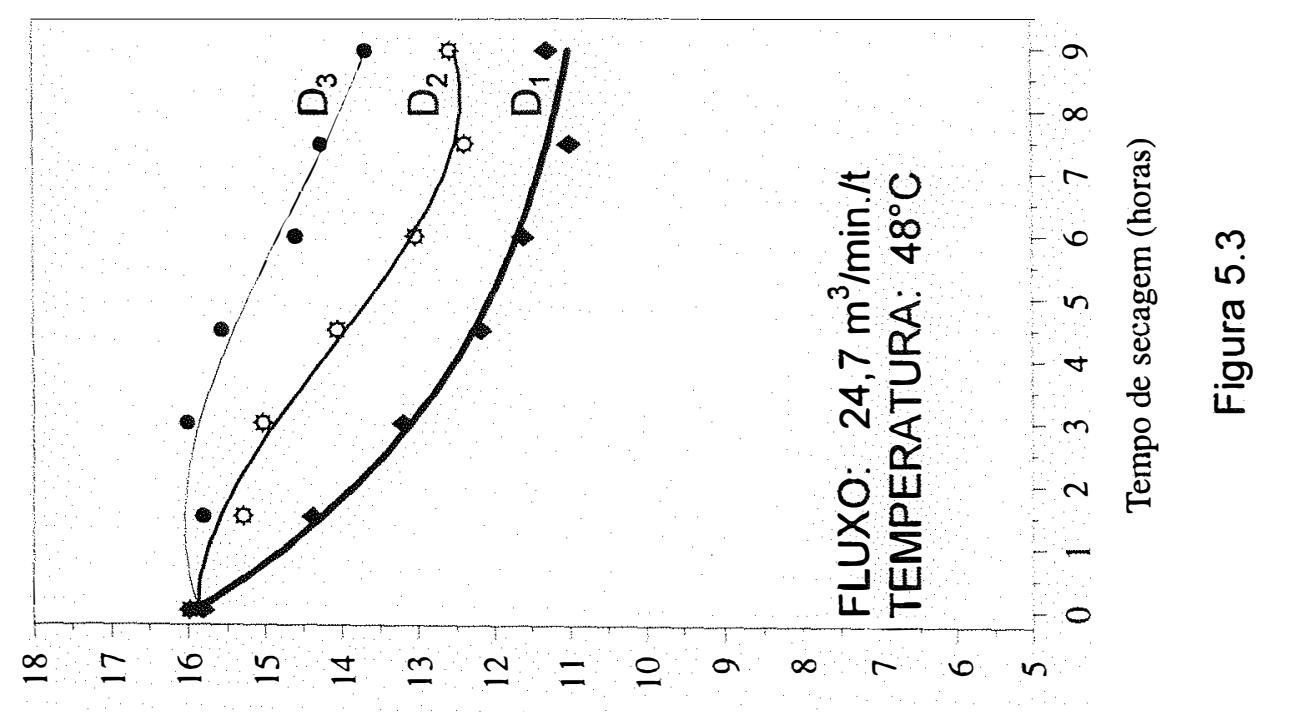

응
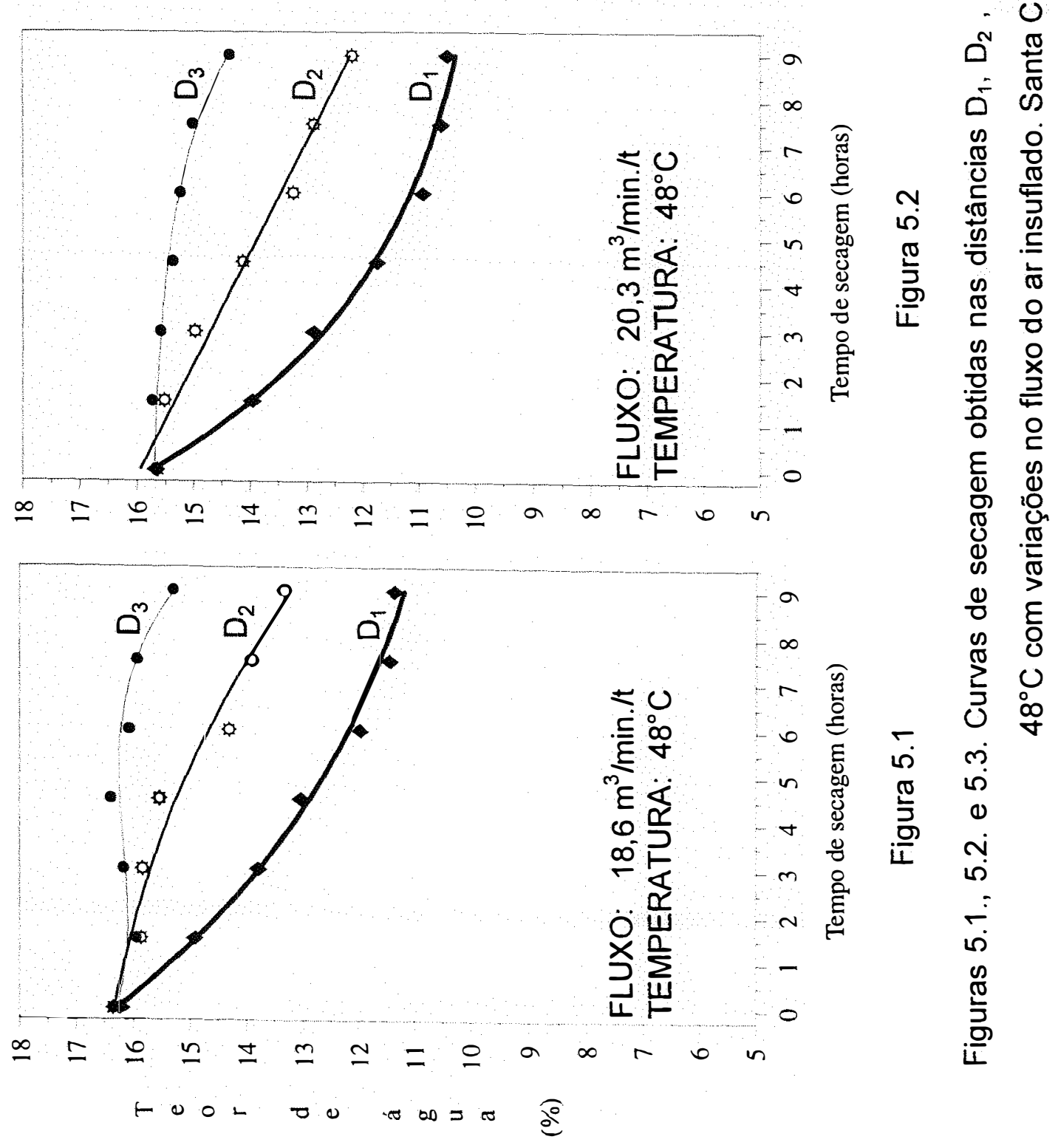
Considerada a distância $D_{3}$, a curva de secagem indicou lentidão na perda de água das sementes revertida, lentamente, após $7,5 \mathrm{~h}$; essa constatação, associada ao teor final de água de $14,4 \%$, sugeriu dificuldades de secagem na porção mais distante da entrada do ar aquecido. Entretanto, considerando o conjunto das três posições, a média ponderada do teor de água final de 12,6\% (Tabela 10) indicou que esta combinação de fluxo e temperatura do ar apresentou condições para secagem satisfatória da massa de sementes.

Com o fluxo de $24,7 \mathrm{~m}^{3} / \mathrm{min} . / \mathrm{t}$, e temperatura do ar de $48^{\circ} \mathrm{C}$, as sementes da distância $D_{1}$ perderam água acentuadamente durante as $4,5 \mathrm{~h}$ iniciais, de tal forma que, após $7,5 \mathrm{~h}$, o teor de água de $11,1 \%$ não foi mais alterado. Na distância $\mathrm{D}_{2}$, a redução do teor de água das sementes, do mesmo modo que em $D_{1}$, deixou de existir após $7,5 \mathrm{~h}$ de secagem com a estabilização do teor de água em torno de $12,5 \%$. No caso de $D_{3}$, a secagem, evidenciada a partir de $3 \mathrm{~h}$ operacionais, conduziu o teor de água das sementes para $13,7 \%$. Dessa maneira, a média ponderada do teor de água da massa correspondeu a $12,6 \%$ e revela que o fluxo de $24,7 \mathrm{~m}^{3} / \mathrm{min}$./t, combinado com a temperatura de $48^{\circ} \mathrm{C}$, apresenta-se como satisfatório para executar secagem da carga do secador.

A secagem estacionária de sementes, com distribuição radial do ar insuflado, constitui-se em técnica demandadora de definições quanto aos 
parâmetros operacionais, uma vez que os dados disponiveis referem-se, primordialmente, à secagem estacionária com distribuição axial do ar. Desse modo, a ausência de informações especificas, que subsidiem confrontações entre pesquisas similares, dificulta a discussão comparativa de dados obtidos.

Periodos, de até 20 horas, são admitidos como adequados para a realização da secagem estacionária de sementes (Dalpasquale, 1987). Contudo, a aceleração da operação, desde que respeitados limites máximos para a deterioração imposta às sementes, é vantajosa sob os aspectos de economia energética e de aproveitamento de equipamentos. Observou-se que a relação, entre o teor de água das sementes e o tempo de secagem, foi representada por diferentes funções dependentes da combinação fluxotemperatura e da distância das sementes em relação ao ponto de injeção do ar aquecido na massa.

Considerando a distância $D_{1}$, as curvas de secagem concordaram, aproximadamente, com as referidas por Kreyger (1973), Westerman et al. (1973), Brooker et al. (1974), Hall (1980) e Baker et al. (1991) para camadas delgadas. Todavia, o periodo de indução, caracterizado por elevação da temperatura das sementes até a estabilização, e o de velocidade constante, no qual as transferências de calor e massa se equivalem, não foram claramente definidos. Durante a secagem, o periodo de velocidade constante pode não existir quando a evaporação da água superficial é superior ao 
deslocamento da água interna para a superfície das sementes (Kreyger, 1973; Brooker et al., 1974; Hall, 1980).

O periodo de velocidade decrescente foi caracterizado, em $D_{1}$, nas ocasiões em que a temperatura das sementes, elevando-se, tendeu a aproximar-se da temperatura do ar de secagem. Tal comportamento era previsivel uma vez que, estando as sementes próximas à entrada do ar, houve ampla transferência de energia calorífica e, por consequência, a evaporação foi intensificada. Esta elevação da temperatura das sementes foi, possivelmente, conseqüência de insuficiência no deslocamento da água do interior para a superficie da semente e decorrente desequilibrio nas trocas de calor e de massa (Kreyger, 1973; Brooker et al., 1974; Hall, 1980). A ampliação da dificuldade de evaporação da água com a redução do grau de umidade das sementes, conforme Nellist \& Hughes (1973), resulta do aumento da força molecular de adesão da água aos colóides e exige gasto adicional de energia; os autores consideram $14 \%$ de água como sendo o limite abaixo do qual há aumento significativo na necessidade de energia para evaporar água de sementes de milho que, segundo Coates (1960), é de 15 a $20 \%$ superior à demandada na evaporação da água livre.

Aparentemente, as funções lineares, representantes do comportamento do teor de água das sementes durante a secagem, foram contrárias às colocações de Kreyger (1973), Westerman et al. (1973), Brooker 
et al. (1974) e Hall (1980). De acordo com esses autores, a curva característica de secagem apresenta um período curto ou ausente, de velocidade constante, seguido da combinação de uma série de segmentos retilíneos e curvilíneos. Todavia, as funções lineares, que expressaram algumas das curvas de secagem obtidas, podem representar segmento parcial da curva característica que, nos estudos, foi obtida em camadas delgadas, sob condições uniformes de temperatura, de umidade relativa e, adicionalmente, com significativa diferença entre os teores de água inicial e final do produto.

No início da secagem, ao absorver água da massa próxima ao cilindro central, o ar insuflado pode, em seu deslocamento, hidratar as sementes ainda não atingidas pela frente de secagem. Considerando as sementes da distância $D_{2}$, a perda de água, em geral, ocorreu de forma lenta, inicialmente, e mais acentuadamente a partir de determinado tempo de secagem, variável com os fluxos e temperaturas do ar empregados. Com referência às sementes da distância $D_{3}$, verificou-se, em algumas situações, a manutenção, ou mesmo acréscimo, do grau de umidade nos momentos iniciais de secagem.

O momento, a partir do qual a remoção de água tornou-se mais significativa, correspondeu, possivelmente, ao da chegada da frente de secagem à posição, quando o intercâmbio de fluxo e massa se intensifica promovendo o início de elevação da temperatura das sementes (Matthes \& 
Rushing, 1972; Boyd et al., s.d.). Em $D_{3}$, maior distância considerada à região de insuflação do ar, a frente de secagem, praticamente, não agiu nas combinações entre os fluxos de 18,6 e $20,3 \mathrm{~m}^{3} / \mathrm{min}$./t e as temperaturas de 40 e $44^{\circ} \mathrm{C}$; sob os mesmos fluxos e temperatura de $48^{\circ} \mathrm{C}$, a ação foi apenas iniciada no final do período experimental. Por outro lado, o fluxo de 24,7 $\mathrm{m}^{3} / \mathrm{min} . / \mathrm{t}$, apesar de igualmente aumentar de eficiência com a elevação da temperatura, proporcionou a chegada da frente de secagem na distância $D_{3}$, em todas as combinações das quais participou. Deste modo, o deslocamento da frente de secagem foi, principalmente, determinado pelo fluxo de ar, em concordância com as afirmações de Boyd et al. (1974), Zimmer (1989), Paula (1992) e Biagi et al. (1992).

A velocidade de secagem (Tabela 12), dependente do caminhamento da frente de secagem, foi reduzida na medida em que foi aumentada a distância das sementes ao cilindro central. A elevação do fluxo contribuiu mais acentuadamente, para o aumento da velocidade, do que a da temperatura. Os dados verificados, principalmente nas temperaturas de $40 \mathrm{e}$ $44^{\circ} \mathrm{C}$, indicaram superioridade na velocidade de secagem proporcionada pelo maior fluxo $\left(24,7 \mathrm{~m}^{3} / \mathrm{min} . / \mathrm{t}\right)$ em relação aos demais.

Como produto predominantemente amiláceo, e portanto higroscópico, as sementes de milho são classificadas como de secagem lenta ou intermediária (Kreyger, 1973; Biagi et al., 1992; Villela, 1991). De acordo 
com Biagi et al. (1992), a aceleração da secagem, neste tipo de produto, pode ocasionar, além da evaporação da água, a volatilização e decomposição de substâncias orgânicas com consequentes prejuízos à qualidade. Remoções horárias de água próximas à $2 \%$, conjugadas com rápido aquecimento da massa, são, segundo Herter \& Burris (1989b), fatores indutores de efeitos prejudiciais às sementes de milho.

Muito embora Kreyger (1973) não tenha especificado valores ao considerar o milho como de secagem lenta, Villela (1991), utilizando o método intermitente e temperaturas do ar de 70,80 e $90^{\circ} \mathrm{C}$, encontrou velocidades máximas de secagem de $0.79 \% \mathrm{H}_{2} \mathrm{O} / \mathrm{h}$. Mclean (1980) observou que, em secador estacionário com distribuição radial de ar, a utilização de elevados fluxos pode proporcionar velocidades de secagem de 0,16 a $0,20 \%$ $\mathrm{H}_{2} \mathrm{O} / \mathrm{h}$, em $20 \mathrm{~h}$ de secagem, inferiores às de 0,20 a $0,52 \% \mathrm{H}_{2} \mathrm{O} / \mathrm{h}$ obtidas, no presente trabalho, em $9 \mathrm{~h}$ operacionais.

Todavia, considerando os teores de água finais da massa de sementes, a remoção minima de $0,33 \% \quad \mathrm{H}_{2} \mathrm{O} / \mathrm{h}$, proporcionada pelas combinações de $20,3 \mathrm{~m}^{3} / \mathrm{min} . / \mathrm{t}$ com $48^{\circ} \mathrm{C}$ e de $24,7 \mathrm{~m}^{3} / \mathrm{min} . / \mathrm{t}$ com 40,44 e $48^{\circ} \mathrm{C}$, foi a exigida para possibilitar a secagem adequada. Por outro lado, fixado o fluxo de $24,7 \mathrm{~m}^{3} / \mathrm{min}$./t, houve, contrariando o esperado, superioridade de velocidade sob $44^{\circ} \mathrm{C}$ em relação a $48^{\circ} \mathrm{C}$; neste caso, provavelmente, a taxa de remoção de água tenha sido afetada, negativamente, por limitações na difusão 
da umidade interna para a superfície das sementes, conforme o relatado por Nellist \& Hughes (1973), Brooker et al. (1974) e Biagi et al. (1992).

O fluxo de ar acha-se diretamente associado à uniformidade de secagem da massa (Brandenburg et al., 1961; Biagi et al., 1992). De acordo com os primeiros autores, a utilização de fluxos de ar, entre 22 e $44 \mathrm{~m} / \mathrm{min} . / \mathrm{t}$, possibilita atingir esse objetivo na secagem de sementes; no entanto, particularmente no método estacionário, ocorre desuniformidade do teor de água, entre porções diferentemente distanciadas da entrada do ar aquecido, minorada com a redução da espessura da massa (Brooker et al., 1974; Mclean, 1980; Dalpasquale, 1987; Corrêa, 1981; Pasin, 1991). No decorrer da secagem, os gradientes de umidade foram, em geral, crescentes com o andamento da operação; todavia, dentro de cada temperatura, houve similaridade entre os valores encontrados para os fluxos de 18,6 e 20,3 $\mathrm{m}^{3} / \mathrm{min} . / \mathrm{t}$ (Tabela 11) e, paralelamente, tendência de redução nos obtidos com $24,7 \mathrm{~m}^{3} / \mathrm{min} . / \mathrm{t}$, em conformidade com as colocações de Brooker et al. (1974) e Biagi et al. (1992) sobre o assunto.

Fixados os fluxos, o aumento da temperatura associou-se à elevação do gradiente de umidade excetuando-se, entretanto, a combinação do maior fluxo com a maior temperatura onde, provavelmente, passaram a prevalecer os efeitos contrários promovidos pelo fluxo. Apesar da influência indesejada que a temperatura do ar de secagem exerce sobre o gradiente de 
umidade das sementes, o seu aumento pode ser recomendável, em situações especificas, com o intuito de reduzir, temporariamente, o tempo de secagem (Dalpasquale, 1987). Sob este aspecto, os resultados indicaram a validade de utilização da temperatura de $48^{\circ} \mathrm{C}$. No entanto, conforme Gustafson et al. (1978) e Gustafson \& Morey (1979), as altas temperaturas concorrem para aumentar a susceptibilidade das sementes a danos físicos nos manejos da massa.

No final da secagem, os gradientes de umidade oscilaram (Tabela 11) em torno de valores próximos aos verificados em sementes de arroz (Corrêa, 1981) e de soja (Pasin, 1991) submetidas à ação de equipamento semelhante. Mclean (1980) e Dalpasquale (1987) ponderaram que os gradientes, normalmente observados, não causam efeitos prejudiciais às sementes uma vez que, na descarga do secador, ocorre mistura suficiente para equalizar a distribuição de umidade pela massa.

Desse modo, levados em conta os aspectos físicos, o fluxo de $24,7 \mathrm{~m} / \mathrm{min} . / \mathrm{t}$ foi o mais eficiente, no aproveitamento do calor, para realizar a secagem. Contudo, quando aplicado em combinação com a temperatura de $48^{\circ} \mathrm{C}$, apresentou inconveniências, relativas à redução da velocidade de secagem, não verificadas a $44^{\circ} \mathrm{C}$. 


\subsection{Conseqüências provocadas às sementes}

O teor de água das sementes (Tabela 16), no início do armazenamento, apresentou variações, entre os tratamentos, iguais ou inferiores a $1,7 \%$ e valores máximos de $12,4 \%$. Com isso, foi possivel assegurar uma relativa uniformidade para o fator entre os tratamentos e, assim, minimizar a sua influência nas confrontações dos efeitos fisiológicos provenientes das secagens.

Nas Tabelas 17, 18 e 19 são dispostos os resultados da análise de variância (teste F) e os dados concernentes à avaliação da qualidade das sementes, no início (efeitos imediatos) e no final (efeitos latentes) do período de armazenamento, em função das distâncias e tempos de secagem.

Foi detectada, em todos os testes realizados, a ausência de efeitos imediatos provenientes da duração da secagem e da posição das sementes na massa. Esse mesmo comportamento persistiu ao final do armazenamento, excetuando-se nas indicações fornecidas pelos testes de germinação e de comprimento de raiz; nestes casos, as variações de desempenho surgidas, possivelmente oriundas de fatores não controlados durante a realização dos testes, foram desordenadas e não pareceram indicar quaisquer tendências. 
Tabela 16. Dados do teor de água das sementes de milho, submetidas a diferentes tempos de secagem com variações no fluxo e na temperatura do ar insuflado, no início ( 0 mês) e no final ( 6 meses) do armazenamento. Santa Cruz das Palmeiras-SP, 1995.

\begin{tabular}{|c|c|c|c|c|c|c|c|c|}
\hline \multicolumn{2}{|c|}{ TRATAMENTOS } & \multirow{3}{*}{$\begin{array}{l}\text { TS } \\
\text { (h) }\end{array}$} & \multirow{2}{*}{\multicolumn{3}{|c|}{$\begin{array}{c}\text { OMES } \\
\text { DISTÁNCIAS }\end{array}$}} & \multirow{2}{*}{\multicolumn{3}{|c|}{$\begin{array}{l}6 \text { MESES } \\
\text { DISTANCIAS }\end{array}$}} \\
\hline \multirow[b]{2}{*}{$\mathrm{F}\left(\mathrm{m}^{3} / \mathrm{min} . / \mathrm{t}\right)$} & \multirow[b]{2}{*}{$\mathrm{T}\left({ }^{\circ} \mathrm{C}\right)$} & & & & & & & \\
\hline & & & $D_{1}$ & $D_{2}$ & $D_{3}$ & $D_{1}$ & $D_{2}$ & $D_{3}$ \\
\hline \multirow[t]{4}{*}{18,6} & 40 & 0,0 & 10,4 & 10,6 & 10,7 & $\overline{10,1}$ & 10,2 & 10,2 \\
\hline & & 3,0 & 11,2 & 11,2 & 11,1 & 10,3 & 10,5 & 10,7 \\
\hline & & 6,0 & 11,8 & 11,5 & 11,4 & 10,4 & 10,4 & 10,5 \\
\hline & & 9,0 & 11,6 & 11,7 & 11,1 & 10,5 & 10,1 & 10,2 \\
\hline \multirow[t]{4}{*}{20,3} & 40 & 0,0 & 11,7 & 11,7 & 11,8 & $\overline{10,1}$ & 10,4 & 10,3 \\
\hline & & 3,0 & 11,9 & 12,2 & 12,1 & 10,6 & 10,7 & 10,6 \\
\hline & & 6,0 & 12,1 & 12,2 & 12,2 & 10,8 & 10,7 & 11,2 \\
\hline & & 9,0 & 12,2 & 12,2 & 11,9 & 11,0 & 11,1 & 10,8 \\
\hline \multirow[t]{4}{*}{24,7} & 40 & 0,0 & 11,2 & 11,2 & 11,1 & 10,2 & 10,3 & 10,4 \\
\hline & & 3,0 & 11,4 & 11,6 & 11,5 & 10,5 & 10,5 & 10,6 \\
\hline & & 6,0 & 11,6 & 11,5 & 11,8 & 10,4 & 10,4 & 10,5 \\
\hline & & 9,0 & 12,0 & 11,9 & 11,7 & 10,5 & 10,5 & 10,4 \\
\hline \multirow[t]{4}{*}{18,6} & 44 & 0,0 & 12,2 & 11,9 & 12,1 & 10,1 & 10,3 & 10,2 \\
\hline & & 3,0 & 11,9 & 12,1 & 12,1 & 10,3 & 10,5 & 10,7 \\
\hline & & 6,0 & 12,2 & 12,4 & 11,6 & 10,5 & 10,6 & 10,1 \\
\hline & & 9,0 & 11,9 & 12,0 & 11,8 & 10,1 & 10,4 & 10,2 \\
\hline \multirow[t]{4}{*}{20,3} & 44 & 0,0 & 11,8 & 11,6 & 12,2 & 10,7 & 10,6 & 10,4 \\
\hline & & 3,0 & 12,2 & 12,3 & 12,2 & 10,9 & 10,8 & 10,9 \\
\hline & & 6,0 & 12,1 & 11,7 & 11,7 & 11,0 & 10,6 & 10,7 \\
\hline & & 9,0 & 11,6 & 11,9 & 11,9 & 10,4 & 10,4 & 10,7 \\
\hline \multirow[t]{4}{*}{24,7} & 44 & 0,0 & 11,5 & 11,6 & 11,9 & 10,6 & 10,3 & 10,4 \\
\hline & & 3.0 & 11,6 & 11,6 & 11,9 & 10,7 & 10,4 & 10,5 \\
\hline & & 6,0 & 11,8 & 11,7 & 11,4 & 10,6 & 10,3 & 10,6 \\
\hline & & 9,0 & 11,3 & 11,3 & 11,5 & 10,6 & 10,2 & 10,4 \\
\hline \multirow[t]{4}{*}{18,6} & 48 & 0,0 & 11,6 & 11,4 & 11,6 & 10,2 & 10,2 & 10,3 \\
\hline & & 3,0 & 11,4 & 11,3 & 11,8 & 10,2 & 10,3 & 10,6 \\
\hline & & 6,0 & 12,0 & 11,8 & 12,1 & 10,7 & 10,5 & 10,8 \\
\hline & & 9,0 & 12,0 & 11,9 & 11,9 & 10,8 & 10,3 & 10,4 \\
\hline \multirow[t]{4}{*}{20,3} & 48 & 0,0 & 11,8 & 11,5 & 11,6 & 10,5 & 10,4 & 10,3 \\
\hline & & 3,0 & 11,8 & 11,4 & 11,1 & 10,6 & 10,3 & 10,2 \\
\hline & & 6,0 & 11,3 & 11,6 & 11,6 & 10,6 & 10,4 & 10,5 \\
\hline & & 9,0 & 11,7 & 11,5 & 11,7 & 10,8 & 10,3 & 10,3 \\
\hline \multirow[t]{4}{*}{24,7} & 48 & 0,0 & 12,0 & 11,8 & 12,2 & 10,5 & 10,7 & 10,8 \\
\hline & & 3,0 & 12,0 & 12,1 & 11,5 & 10,7 & 10,5 & 10,6 \\
\hline & & 6,0 & 11,9 & 11,7 & 12,1 & 10,5 & 10,4 & 10,7 \\
\hline & & 9,0 & 11,8 & 12,0 & 12,0 & 10,6 & 10,6 & 10,7 \\
\hline
\end{tabular}

Legenda:

$F$ - fluxo de ar insuflado

$T$ - temperatura do ar insuflado

TS - tempo de secagem 


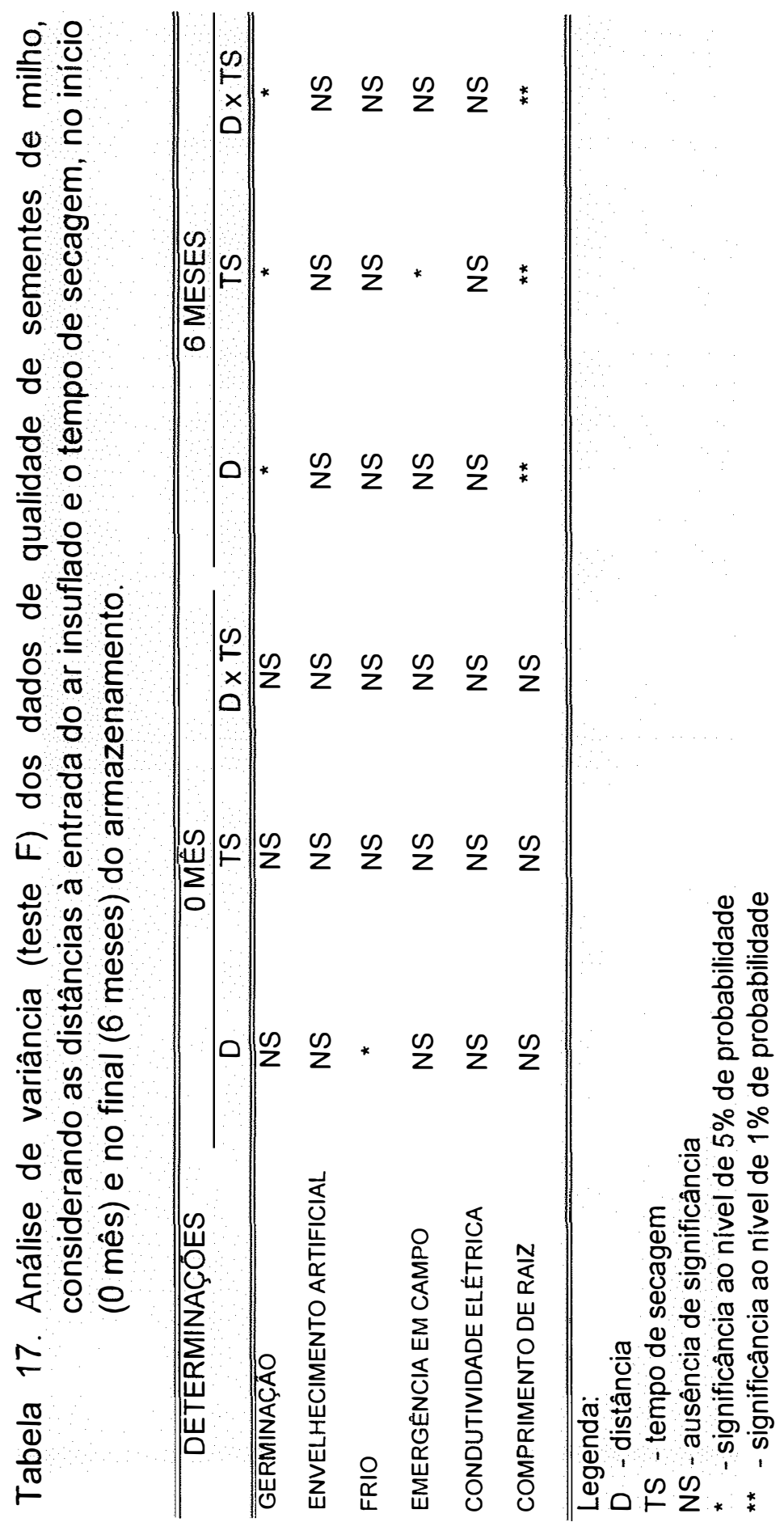




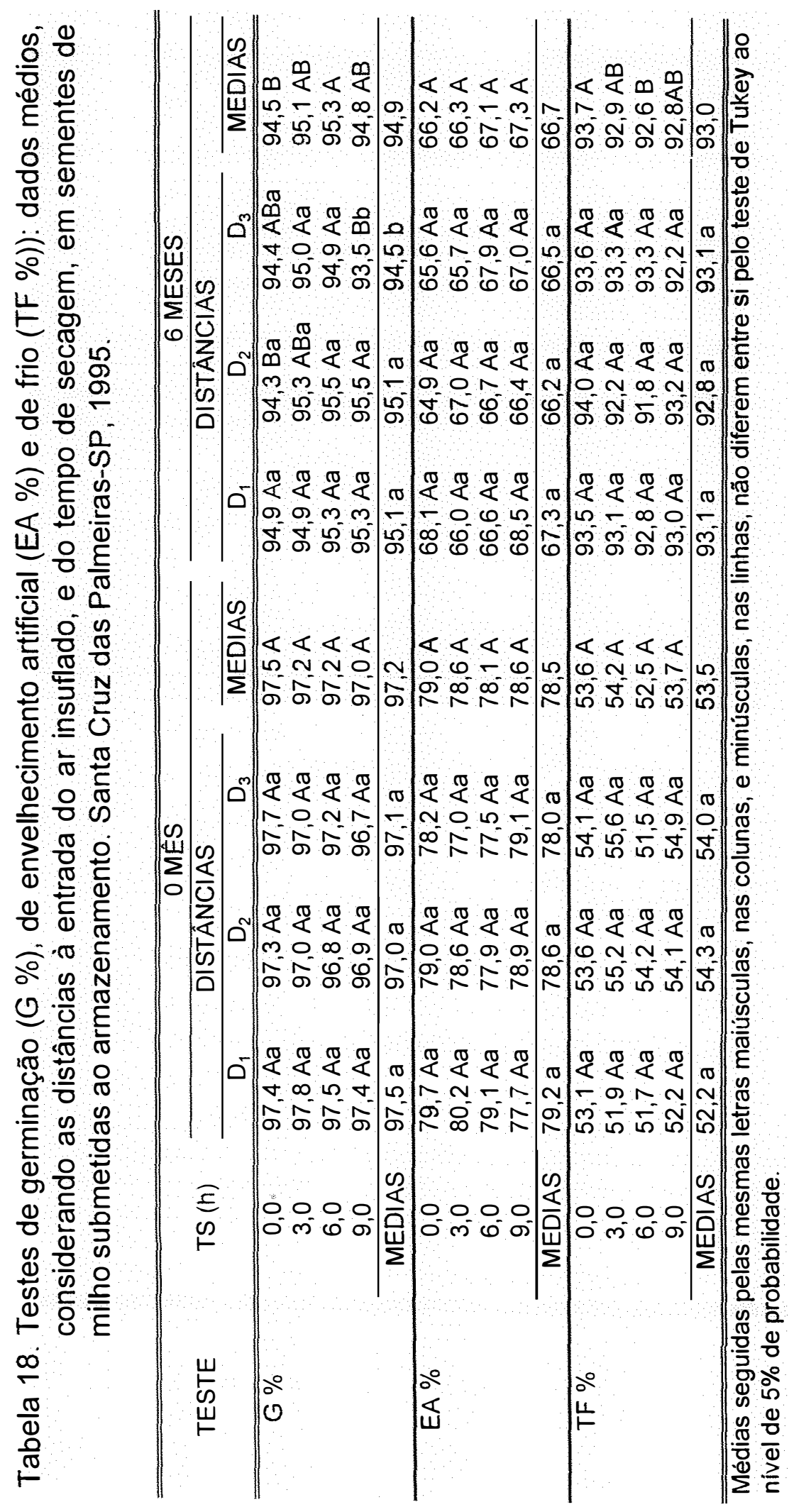




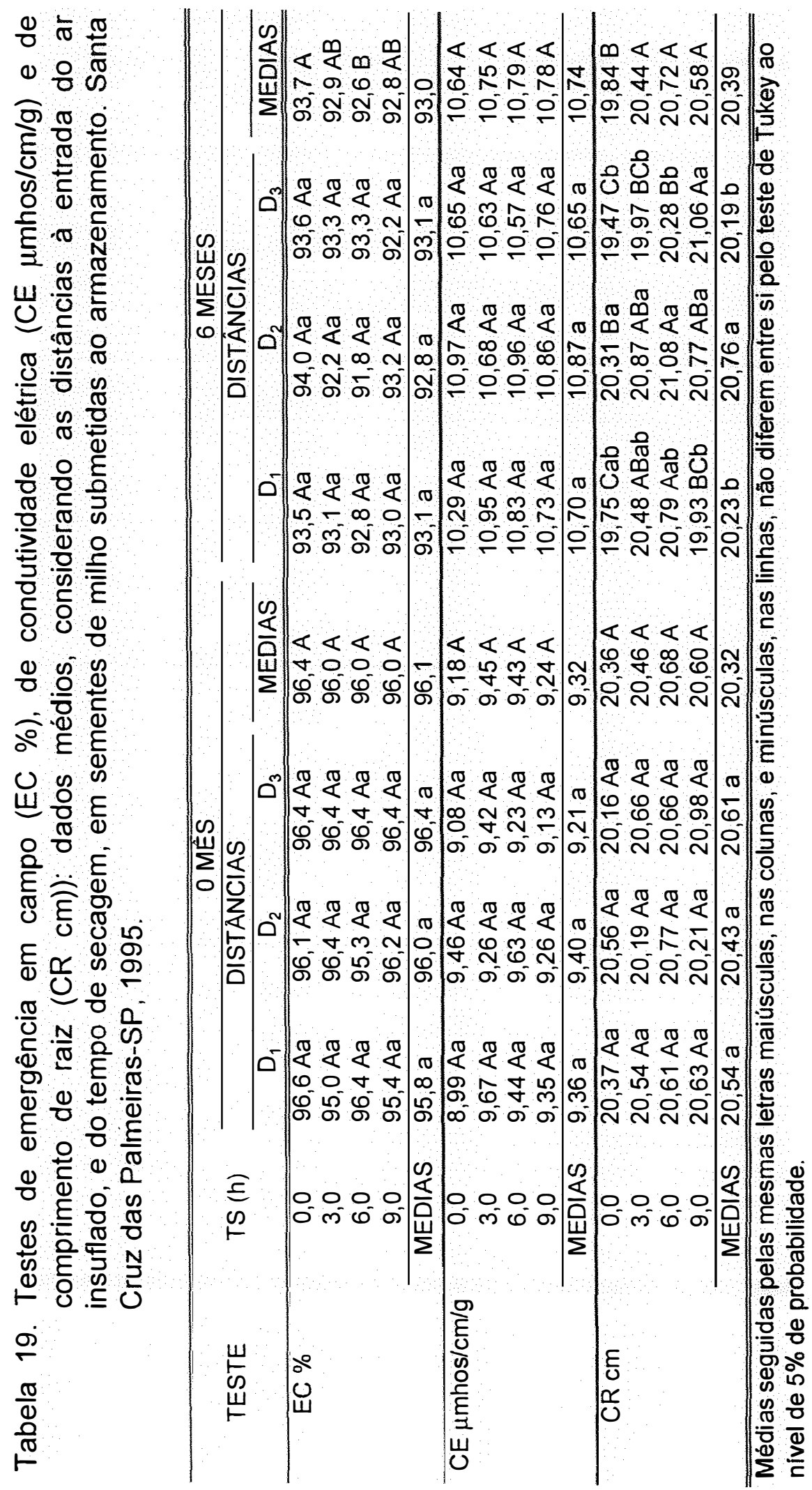


A inexistência de efeitos fisiológicos nas sementes, provenientes do posicionamento na massa, foi igualmente observada em secagens estacionárias com fluxo radial (Mclean, 1980; Corrêa, 1981; Pasin, 1991) e axial do ar (Boyd et al., s.d.).

Conforme Tabelas 4,5 e 6 , a massa de sementes não ultrapassou a temperatura de $45^{\circ} \mathrm{C}$, considerada como crítica por Brooker et al. (1974), Matthes \& Rushing (1972) e Biagi et al. (1992), mesmo quando o ar insuflado apresentava-se com $48^{\circ} \mathrm{C}$. Assim, as variações registradas na massa para o grau de umidade e para temperatura (Tabelas 7 e 11), não determinaram efeitos fisiológicos às sementes, corroborando as informações de Mclean (1980), Corrêa (1981) e Pasin (1991).

A análise estatística (teste F) e os dados de qualidade fisiológica, referentes ao início e final do armazenamento, em função dos fluxos e temperaturas do ar insuflado, são apresentados nas Tabelas 20, 21 e 22.

Os testes empregados foram, comparativamente, desuniformes quanto às indicações fornecidas e, dessa forma, confirmaram a dificuldade tecnológica, ainda existente, para a seleção das determinações destinadas à avaliação da qualidade fisiológica de sementes. Surgiram, de maneira geral, interações entre os dois fatores. 


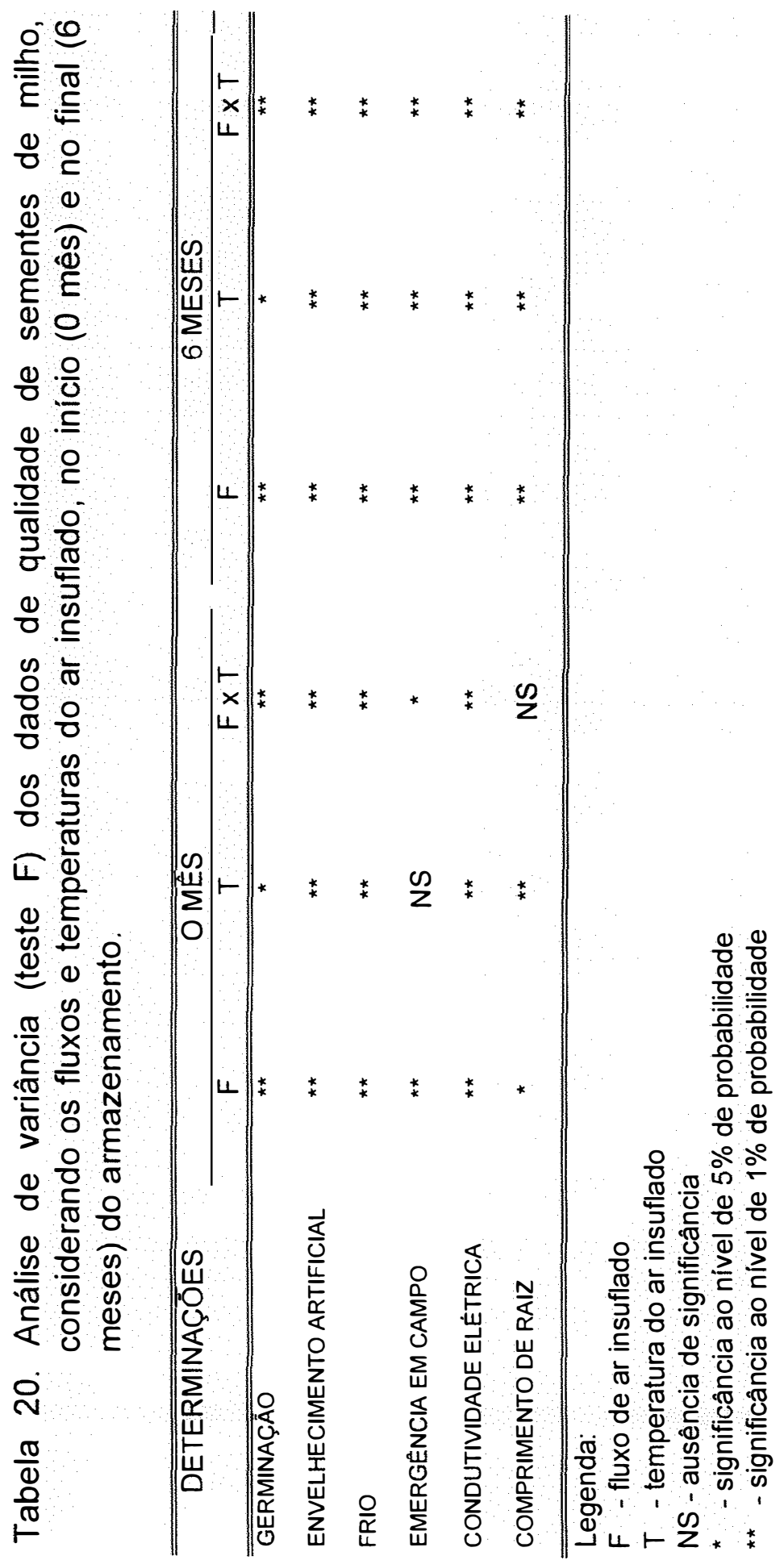




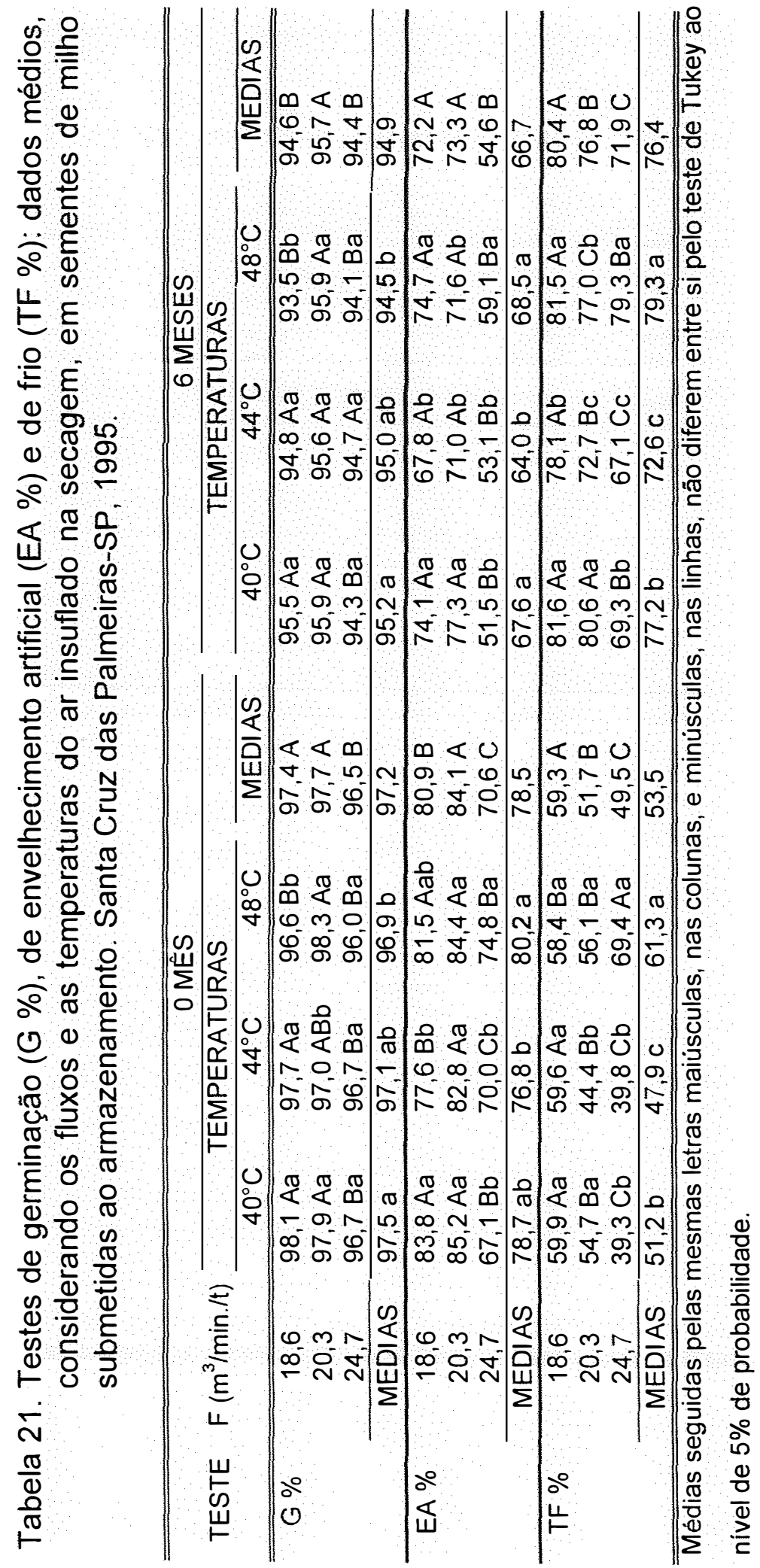




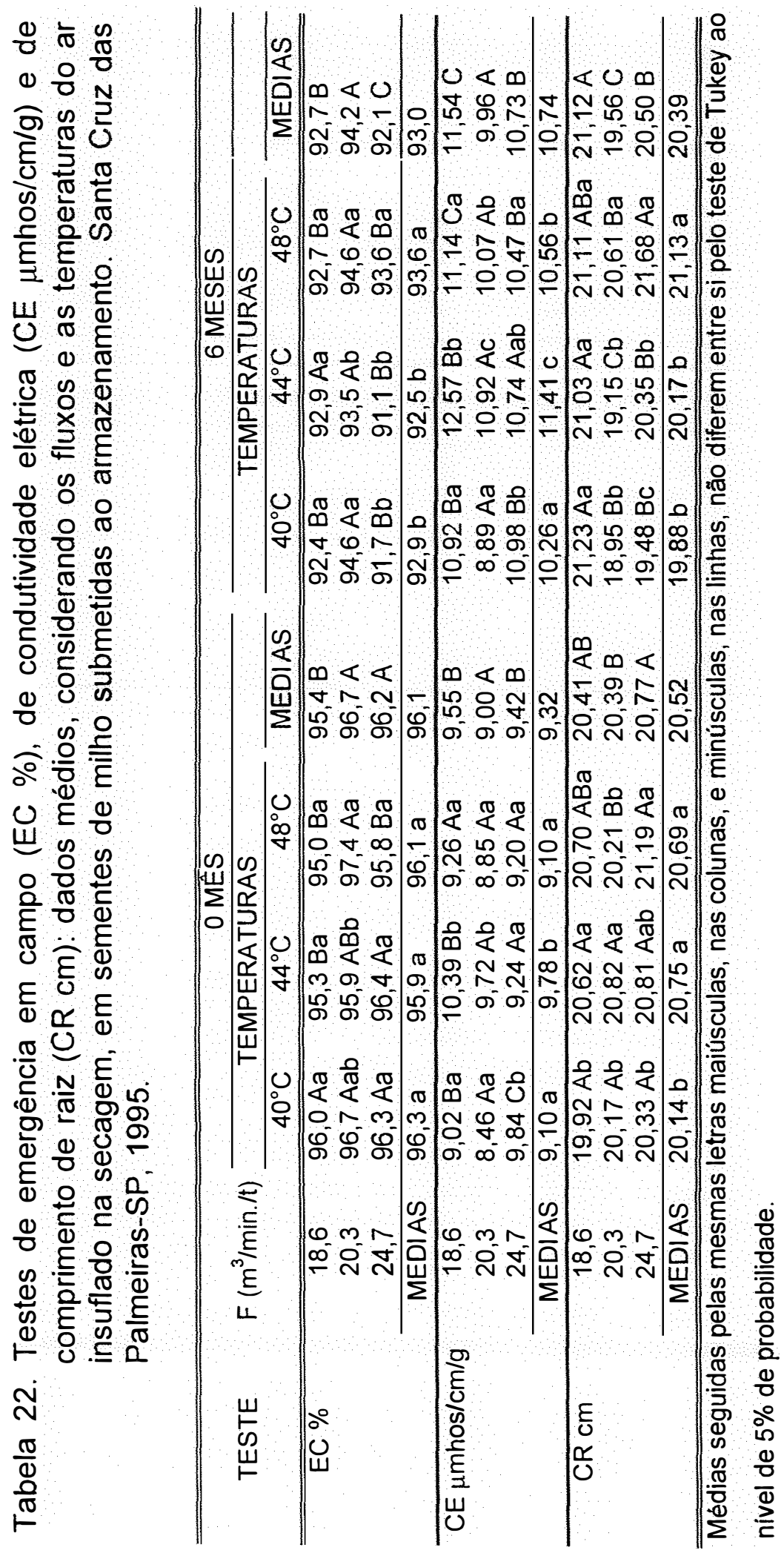


Fixada a temperatura de $40^{\circ} \mathrm{C}$, a elevação do fluxo tendeu a gerar prejuízos imediatos e latentes evidenciados, nos testes de germinação, de envelhecimento artificial e de frio, pela inferioridade de desempenho do maior fluxo $\left(24,7 \mathrm{~m}^{3} / \mathrm{min} . / \mathrm{t}\right)$ na comparação com os demais; entre os outros fluxos, apesar de presente, esse comportamento foi menos marcante. Sob $44^{\circ} \mathrm{C}$, a elevação do fluxo manteve a mesma tendência observada a $40^{\circ} \mathrm{C}$; contudo, quando avaliados os efeitos imediatos, nos testes de condutividade elétrica, comprimento de raiz e emergência em campo, o menor fluxo $(18,6$ $\mathrm{m}^{3} / \mathrm{min} . / \mathrm{t}$ ), foi o mais desvantajoso. Durante o uso da temperatura de $48^{\circ} \mathrm{C}$, os dados não definiram, claramente, o comportamento relativo dos fluxos; no entanto, principalmente nos efeitos latentes, o fluxo intermediário $(20,3$ $\mathrm{m}^{3} / \mathrm{min} \cdot(\mathrm{t})$ tendeu a destacar-se positivamente dos demais.

Fixando o fluxo de $18,6 \mathrm{~m}^{3} / \mathrm{min}$./t, o uso da menor temperatura $\left(40^{\circ} \mathrm{C}\right)$, no conjunto dos testes, foi o mais favorável ao desempenho fisiológico. Sob o fluxo de $20,3 \mathrm{~m}^{3} / \mathrm{min} \cdot / \mathrm{t}$, apesar de mais evidentemente nos efeitos latentes, essa superioridade da temperatura de $40^{\circ} \mathrm{C}$ foi mantida. Todavia, no fluxo de $24,7 \mathrm{~m}^{3} / \mathrm{min} . / \mathrm{t}$, a temperatura de $48^{\circ} \mathrm{C}$, tanto no início quanto no final do armazenamento, foi a mais vantajosa.

O fluxo e a temperatura do ar insuflado, apesar de destacados na literatura como relacionados aos danos fisiológicos provocados às sementes durante a secagem estacionária (Westerman et al., 1973; Boyd, 1974; Herter \& 
Burris, 1989a, Pasin, 1991; Carvalho, 1994), têm as suas interações pouco conhecidas e, em alguns casos, abordadas através da interpretação dos efeitos promovidos pela velocidade de secagem (Meier, 1983; Navratil \& Burris, 1984). Sob esse aspecto, a definição das temperaturas operacionais tem se constituído no principal referencial de apoio tecnológico empregado na secagem, independentemente das suas relações com o fluxo que, conforme 0 observado, participa diretamente do resultado final do processo.

Assim, levando em conta as tendências gerais observadas, verificou-se que reduções ou aumentos conjuntos nos valores do fluxo e da temperatura, admitidos os intervalos experimentais testados, beneficiou a preservação da qualidade fisiológica das sementes. 


\section{CONCLUSÕES}

Considerando os intervalos de 18,6 a $24,7 \mathrm{~m}^{3} / \mathrm{min} . / \mathrm{t}$, e de 40 a $48^{\circ} \mathrm{C}$, respectivamente para o fluxo e a temperatura do ar insuflado, pode-se concluir que o aumento conjunto nos valores de ambos os fatores, além de físicamente eficiente, permite evitar efeitos negativos, advindos da secagem, na qualidade fisiológica das sementes de milho. Dessa forma, a combinação de $24,7 \mathrm{~m}^{3} / \mathrm{min} . / \mathrm{t} \mathrm{com} 48^{\circ} \mathrm{C}$ pode ser recomendada. 


\section{REFERÊNCIAS BIBLIOGRÁFICAS}

ALVARENGA, L.C. Transporte de água em grãos de feijão preto sob condições de secagem e repouso. Viçosa, 1979. 58 p. Dissertação (M.S.) Universidade Federal de Viçosa.

ANDRIGUETO, J.R.; POPINIGIS, F.; SILVA, J.G.C. Efeitos do retardamento da secagem da semente do trigo (Triticum aestivum L.) sobre sua qualidade fisiológica. Semente, v.2, n.2, p.65-73, 1976.

BAKER, K.D.; PAULSEN, M.R.; ZWEDEN, J.V. Hybrid and drying rate effects on seed corn viability. Tansactions of the ASAE, v.34, n.2, p.499-506, 1991.

BDLIYA, P.M.; BURRIS, J.S. Diallel analysis of tolerance of drying injury in seed corn. Crop Science, v.28, n.6, p.935-938, 1988. 
BIAGI, J.D.; SILVA, I.J.O. Software para determinar as propriedades psicrométricas do ar. In: CONGRESSO BRASILEIRO DE ENGENHARIA AGRíCOLA, 19., Piracicaba, 1990. Anais. Piracicaba: Sociedade Brasileira de Engenharia Agrícola, 1990. p.1161-1175.

BIAGI, J.D.; VALENTINI, S.R.; QUEIROZ, D.M. Secagem de produtos agrícolas. In: MAGALHÃES, P.S.G.; CORTES, L.A.B. (Coord.) Introdução à engenharia agrícola. Campinas: UNICAMP, 1992. cap. 3, p.245-266.

BOUNOUS, E.B. Comparação de métodos de secagem em sementes de azevém anual (Lolium multiflorum L.). Pelotas, 1986. 109 p. Dissertação (Mestrado) - Univesidade Federal de Pelotas.

BOYD, A.H. Drying soybeans for seed in the southern United States. Mississippi: Mississippi State University, s.d. 12p. (MAFES Journal, 3230).

BOYD, A.H. Heated air drying of soybean (Glycine max (L.) Merrill) seed. Mississippi, 1974. 90 p. Thesis (Ph.D.) - Mississippi State University. 
BOYD, A,H.; MATTHES, R.K.; WELCH, G.B. Heated air drying of soybean seed. Mississippi: Mississippi State University, 1974. 17 p. (MAFES Journal, 2840).

BOYD, A.H.; WELCH, G.B.; BASKIN, C.C. Some thoughts on seed drying. Mississippi: Mississippi State University, s.d. 2 p.

BRANDENBURG, N.R.; SIMONS, J.W.; SMITH, L.L. Why and how seeds are dried. Separata de Yearbook of Agriculture-1961, p.295-306, 1961.

BRASIL. Ministério da Agricultura. Secretaria Nacional de Defesa Agropecuária. Regras para análise de sementes. Brasília, 1992. 365 p.

BROOKKER, D.B.; BAKKER-ARKEMA, F.W.; HALL, C.W. Drying cereal grains. Westport: AVI Publishing, 1974. $265 \mathrm{p}$.

CARVALHO, N.M. A secagem de sementes. Jaboticabal: FUNEP, 1994. $165 p$.

CARVALHO, N.M.; NAKAGAWA, J. Sementes: ciência, tecnologia e produção. 3.ed. Campinas: Fundação Cargill, 1988. 424 p. 
CAVARIANI, C. Efeitos da secagem intermitente sobre a qualidade da semente de soja (Glycine max (L.) Merrill). Pelotas, 1983. 128 p. Dissertação (Mestrado) - Universidade Federal de Pelotas.

CAVARIANI, C.; BAUDET, L.M.L. Secagem de sementes. Informe Agropecuário, v.8, n.91, p.44-49, 1982.

CERQUEIRA, W.P. Retardamento da secagem de semente de soja (Glycine max (L.) Merrill). Revista Brasileira de Armazenamento, v.4, n.2, p.56-63, 1979.

CHEN, Y.; BURRIS, J.S. Role of carbohydrates in desiccation tolerance and membrane behavior in maturing maize seed. Crop Science, v.30, p.971975, 1990.

CHEN, Y.; BURRIS, J.S. Desiccation tolerance in maturing maize seed: membrane phospholipid composition and thermal properties. Crop Science, v.30, p.766-770, 1991. 
CICERO, S.M.; VIEIRA, R.D. Teste de frio. In: VIEIRA, R.D.; CARVALHO, N.M. (Coord.) Testes de vigor em sementes. Jaboticabal: FUNEP, 1994. p.151-164.

CLASER, C.A. Efeito da temperatura e da umidade relativa do ar de secagem na germinação de sementes de soja (Glycine $\max ($ L.) Merrill). Viçosa, 1995. 32 p. Dissertação (M.S.) - Universidade Federal de Viçosa.

COATES, E.S. Grain and seed drying fundamentals. In: SHORT COURSE FOR SEEDSMEN, Mississippi State, 1960. Proceedings. Mississippi: Mississippi State University, 1960. p.111-118.

CORREAA, C.F. Secagem de sementes de arroz (Oryza sativa L.) em silo secador com distribuição radial de ar. Pelotas, 1981. 85 p. Dissertação (Mestrado) - Universidade Federal de Pelotas.

CROSS, H.Z. A selection procedure for ear drying-rates in maize. Euphytica, v.34, p.409-418, 1985. 
DALPASQUALLE, V.A.; QUEIROZ, D.M.; PEREIRA, J.A.M.; SINICIO, R. Secagem de grãos em altas temperaturas. Viçosa: CENTREINAR, 1987. $47 p$.

DANIELL, J.W.; CHAPPELL, W.E.; COUCH, H.B. Effect of sublethal and lethal temperatures on plant cells. Plant Physiology, v.44, p.1684-1689, 1969.

FOSTER, C.H. Heated air grain drying. In: SINHA, R.H.; MUIR, W.E. (Ed.) Grain storage:part of a system. Westport: AVI Publishing, 1973. p.185223.

GONZALES, J.C.; PESKE, S.T.; BAUDET, L.M.; SILVA, J.B. Efeitos do retardamento da secagem de sementes de arroz Bluebelle sobre sua qualidade. Tecnologia de Sementes, v.2, n.2, p.27-33, 1979.

GUNASEKARAN, S.; PAULSEN, M.R. Breakage resistance of corn as a function of drying rates. Transactions of the ASAE, v.28, n.6, p.20712076, 1985. 
GUSTAFSON, R.J.; MOREY, R.V. Study of factors affecting quality changes during high-temperature drying. Transactions of the ASAE, v.22, n.4, p.926-932, 1979.

GUSTAFSON, R.J.; MOREY, R.V.; CHRISTENSEN, C.M.; MERONUCK, R.A. Quality changes during high-low temperature drying. Transactions of the ASAE, v.21, n.1, p.161-169, 1978.

HALL, C.W. Drying and storage of agricultural crops. Westport:AVI Publishing, 1980. 382p.

HARRINGTON, J.F. Seed storage and longevity. In: KOZLOWSKI, T.T. Seed biology. New York:Academic Press, 1972. v.3, p.145-245.

HERTER, U.; BURRIS, J.S. Changes in moisture, temperature, and quality of corn seed during high-temperaure drying. Canadian Journal of Plant Science, v.69, n.3, p.749-761, 1989a.

HERTER, U.; BURRIS, J.S. Effect of drying rate and temperature on drying injury of corn seed. Canadian Journal of Plant Science, v.69,n.3, p.763$774,1989 b$. 
HERTER, U.; BURRIS, J.S. Evaluating drying injury on corn seed with a conductivity test. Seed Science and Technology, v.17, p.625-638, 1989c.

HERTER, U.; BURRIS, J.S. Preconditioning reduces the suceptibility to drying injury in corn seed. Canadian Journal of Plant Science, v.69, n.3, p.775789, 1989d.

KOSTER, K.L.; LEOPOLD, A.C. Sugars and desiccation tolerance in seeds. Plant Physiology, v.88, p.829-832, 1988.

KREYGER, J. Practical observations on the drying of seed. Seed Science and Technology, v.1, p.645-670, 1973.

LASSERAN, J.C. Princípios gerais de secagem. Revista Brasileira de Armazenamento, v.3, n.3, p.17-45, 1978.

LASSERAN, J.C. Características técnicas dos secadores. Revista Brasileira de Armazenamento, v.4, n.2, p.4-14, 1979. 
LUZ, C.A.S. Secagem de sementes de arroz em secador intermitente lento. Pelotas, 1986. 103 p. Dissertação (Mestrado) - Universidade Federal de Pelotas.

MACÊDO, G.A.R.; MARQUES NETO, J.; BATISTA, J.S. Secagem à sombra e ao sol de sementes de gramíneas forrageiras. Revista Brasileira de Sementes, v.9, n.3, p.29-37, 1987.

MADDEN, R.F. Early germination physilogy in hybrid maize (Zea mays L.) embryos damaged by high-temperature desiccation. Dissertation Abstracts International. Series B, v.52, n.11, p.5614, 1992.

MAGALHÃES, P.M.; GROTH, D. Efeitos de diversos processos de secagem sobre a qualidade fisiológica de sementes de Brachiaria humidícola. Revista Brasileira de Sementes, v.14, n.2, p.195-200, 1992.

MARCOS FILHO, J. Teste de envelhecimento acelerado. In: VIEIRA, R.D.; CARVALHO, N.M. (Coord.) Testes de vigor em sementes. Jaboticabal: FUNEP, 1994. p.133-149. 
MATTHES, R.K.; RUSHING, K.W. Seed drying and conditioning. In: SHORT COURSE FOR SEEDSMEN, Mississippi State, 1972. Proceedings. Mississippi: Mississippi State University, 1972. p.23-37.

McLEAN, K.A. Drying and combinable crops. Ipswich: Farming, 1980. 280p.

MEIER, J.L. A survey of genotipe susceptibility to drying injury in maize seeds. lowa Seed Science, v.5, n.1, p.4-5, 1983.

MIRANDA, T.R. Secagem intermitente lenta de sementes de soja (Glycine max (L.) Merrill). Pelotas, 1978. 93p. Dissertação (Mestrado) - Universidade Federal de Pelotas.

MOORE, R.P. Effects of mechanical injuries on viability. In: ROBERTS, E. H. Viability of seeds. London: Chapman and Hall, 1974. p.94-113.

NAKAGAWA, J. Testes de vigor baseado na avaliação das plântulas. In: VIEIRA, R.D.; CARVALHO, N.M. (Coord.) Testes de vigor em sementes. Jaboticabal: FUNEP, 1994. p.49-85. 
NAVRATIL, R.J.; BURRIS, J.S. The effect of drying temperature on corn seed quality. Canadian Journal of Plant Science, v.64, p.487-496, 1984.

NELLIST, M.E.; HUGHES, M. Physical and biological processes in the drying of seed. Seed Science and Technology, v.1, n.3, p.613-643, 1973.

PASIN, N.H. Secagem estática de sementes de soja. Informativo da Associação Brasileira de Tecnologia de Sementes, v.2, n.1, p.33-39, 1991.

PAULA, P.R.T. Secagem de sementes de soja em baixas temperaturas e pequenos fluxos de ar. Pelotas, 1992. 68p. Dissertação (Mestrado) Universidade Federal de Pelotas.

PESKE, S.T.; AGUIRRE, R. Manual para operadores de beneficio de semillas(UBS). Cali: CIAT, 1987. 117p.

PESKE, S.T.; BAUDET, L.M. Considerações sobre secagem de sementes. Viçosa: CENTREINAR, 1980. 19p. 
PURDY, J.L.; CRANE, P.L. Influence of pericarp on differential drying rate in mature corn (Zea mays L·), Crop Science, v.7, p.379-381, 1967a.

PURDY, J.L.; CRANE, P.L. Inheritance of drying rate in mature corn (Zea mays L.). Crop Science, v.7, p.294-297, 1967 b.

RANGEL, M.A.S. Secagem estacionária de sementes de arroz com ar ambiente. Pelotas, 1994. 80p. Dissertação (Mestrado) - Universidade Federal de Pelotas.

ROA, G.; VILLA, L.G. Secagem e armazenamento de grãos e sementes em silos mediante a utilização de ar ambiente e com auxílio de coletores solares. Campinas: UNICAMP, 1977. 51p.

ROBERTS, E.H. Storage environment and the control of viability. In: ROBERTS, E.H. (Ed.) Viability of seeds. Syracuse: Syracuse University Press, 1972. cap. 2, p.14-58.

ROBERTS, E.H. Physiology of ageing and its application to drying and storage. Seed Science and Technology, v.9, p.379-372, 1981. 
ROSA, O.S. Temperaturas recomendadas para a secagem de sementes de trigo e arroz utilizando o método intermitente. In: SEMINÁRIO PANAMERICANO DE SEMENTES, 5., Maracay, 1966: s.ed., 1966. p.1-28.

ROSA, O.S. Limpeza, classificação, secagem, tratamento, embalagem e armazenamento de sementes. In: SEMINÁRIO BRASILEIRO DE SEMENTES, 2., Pelotas, 1968. Anais. Pelotas: UFPel, 1968. p.111-112.

SEYEDIN, N.; BURRIS, J.S.; FLYNN, T.E. Physiological studies on the effects of drying temperatures on corn seed quality. Canadian Journal of Plant Science, v.64, p.497-504, 1984.

SHEDD, C.K. Resistance of grains and seed to air flow. Agricultural Engineering, v.34, p.616-619, 1953.

SILVA, W.R. Secagem das sementes. In: CÍCERO, S.M.; MARCOS FILHO, J.; SILVA, W.R. (Org.) Atualização em produção de sementes. Campinas: Fundação Cargill, 1986. p.155-182. 
SOAVE, J.; MORAES, S.A. Medidas de controle das doenças transmitidas por sementes. In: SOAVE, J.; WETZEL, M.M.V.S. Patologia de sementes. Campinas: Fundação Cargill, 1987. p.192-259.

VEGA, C.R. Efeito do método de secagem sobre a qualidade da semente de arroz (Oryza sativa L.). Pelotas, 1989. 123p. Dissertação (Mestrado) Universidade Federal de Pelotas.

VIEIRA, R.D. Teste de condutividade elétrica. In: VIEIRA, R.D.; CARVALHO, N.M. (Coord.) Testes de vigor em sementes. Jaboticabal: FUNEP, 1994. p.103-132.

VILLELA, F.A. Efeitos da secagem intermitente sobre a qualidade de sementes de milho. Piracicaba, 1991. 104p. Tese (Doutorado) - Escola Superior de Agricultura "Luiz de Queiroz", Universidade de São Paulo.

WELCH. J.B. Articles on seed drying. Separata de Seedmen's Digest, p.1-15, 1967. 
WESTERMAN, P.W.; WHITE, G.M.; ROSS, I.J. Relative humidity effect on the high-temperature drying of shelled corn. Transactions of the ASAE, v.16, n. 6, p.1136-1139, 1973.

WETZEL, M.M.V.S. Fungos de armazenamento. In: SOAVE, J.; WETZEL, M.M.V.S. Patologia de sementes. Campinas: Fundação Cargill, 1987. p.260-275.

ZIMMER, G.J. Seca-aeração para sementes de arroz. Pelotas, 1989. 70p. Dissertação (Mestrado) - Universidade Federal de Pelotas.3 